\title{
THE INFLUENCE OF CHEMICAL COMPOSITION ON IGNITION DELAY TIMES OF GASOLINE FRACTIONS
}

\author{
NIMAL NASER ${ }^{{ }^{*}}$, ABDUL GANI ABDUL JAMEEL ${ }^{1}$, ABDUL-HAMID EMWAS ${ }^{2}$, \\ ESHAN SINGH ${ }^{1}$, SUK HO CHUNG ${ }^{1}$, S. MANI SARATHY \\ ${ }^{1}$ King Abdullah University of Science and Technology (KAUST), \\ Clean Combustion Research Center (CCRC), and, \\ Physical Science and Engineering Division (PSE), Thuwal, 23955-6900, Saudi Arabia \\ ${ }^{2}$ King Abdullah University of Science and Technology (KAUST), \\ Core Labs, Thuwal, 23955-6900, Saudi Arabia \\ *Corresponding author: nimal.naser@kaust.edu.sa
}

\section{To cite this article:}

Naser, N., Abdul Jameel, A.G., Emwas, A.H., Singh, E., et al. "The influence of chemical composition on ignition delay times of gasoline fractions". Combust. Flame, 209 (2019), pp. 418-429. 


\title{
THE INFLUENCE OF CHEMICAL COMPOSITION ON IGNITION DELAY TIMES OF GASOLINE FRACTIONS
}

\author{
NIMAL NASER ${ }^{1}{ }^{*}$, ABDUL GANI ABDUL JAMEEL ${ }^{1}$, ABDUL-HAMID EMWAS ${ }^{2}$, \\ ESHAN SINGH ${ }^{1}$, SUK HO CHUNG ${ }^{1}$, S. MANI SARATHY ${ }^{1}$ \\ ${ }^{1}$ King Abdullah University of Science and Technology (KAUST), \\ Clean Combustion Research Center (CCRC), and, \\ Physical Science and Engineering Division (PSE), Thuwal, 23955-6900, Saudi Arabia \\ ${ }^{2}$ King Abdullah University of Science and Technology (KAUST), \\ Core Labs, Thuwal, 23955-6900, Saudi Arabia \\ *Corresponding author: nimal.naser@kaust.edu.sa
}

\begin{abstract}
Tailoring fuel properties to maximize the efficiency of internal combustion engines is a way towards achieving cleaner combustion systems. In this work, the ignition properties along with the chemical composition (expressed as functional groups) of various light distillate (e.g., gasoline) cuts were analyzed to better understand the properties of full boiling range fuels. Various distillation cuts were obtained with a spinning band distillation system, which were then tested in an ignition quality tester (IQT) to obtain their global chemical reactivity (i.e., ignition delay time (IDT)). The distillates were further analyzed with ${ }^{1} \mathrm{H}$ nuclear magnetic resonance (NMR) spectroscopy to identify and quantify various functional groups present in them. Various gasolines of research grade with specific target properties set forth by the Coordinating Research Council (CRC) that are known as FACE (fuels for advanced combustion engines) gasolines were distilled. When fuels with low aromatic content were distilled, the higher boiling point (BP) range (i.e., molecular weight) fractions exhibited lower IDT. However, distilled fractions of fuels with high aromatic content showed an initial decrease in IDT with increasing BP, followed by drastic increase in IDT primarily due to increasing aromatic groups. This study provides an understanding on the contribution of various volatile fractions to the IDTs of a multicomponent fuel, which is of relevance to fuel stratification utilized in gasoline compression ignition (GCI) engines to tailor heat release rates.
\end{abstract}

Keywords: Gasoline; octane sensitivity; autoignition; combustion; ignition delay times; nuclear magnetic resonance 
One novel approach in achieving global requirements for increased engine efficiency and lower overall greenhouse emissions is co-optimization of fuels and engines. In this regard, designing fuels to match engine requirements and operating conditions becomes imperative. Tailoring chemical and physical properties of fuel to suit each combustion mode in various high efficiency concepts could maximize the internal combustion (IC) engine performance benefits.

A homogeneous charge compression ignition (HCCI) engine, a low temperature combustion (LTC) concept engine, relies mainly on fuel chemistry for its operation. While a partially premixed charge compression ignition (PPCI) engine, utilizes both the thermo-physical properties and chemical properties (autoignition tendency, given by octane number $(\mathrm{ON})$ or cetane number $(\mathrm{CN}))$, to achieve ultra low engine-out emissions as well as high (compression ignition (CI)-like) efficiencies. Similarly, the efficiency of spark ignition (SI) engine depends mostly on the chemical properties (autoignition tendency) of the fuel-air mixture. A fuel exhibiting high resistance to autoignition will allow knock-free operation at high loads, and hence allows higher compression ratio and/or advanced spark timing. In effect, it can be said that an interplay of both the physical and chemical properties of any fuel contributes to the performance of a given engine.

Furthermore, in LTC concepts, such as PPCI, it is desirable to inject a relatively high $\mathrm{ON}$ fuel early in the compression stroke. This allows partial premixing of the fuel and air before combustion takes place [1-3]. Such premixing reduces localized high temperature rich zones thereby suppressing soot formation, while the innate low temperature operation results in negligible $\mathrm{NO}_{x}$ formation [3, 4]. Proper implementation of such a concept relies on carefully timing the combustion event over a range of load and speed.

$\mathrm{ON}$ is a representative of autoignition of end gas when running an SI engine on a specified fuel. A fuel having higher $\mathrm{ON}$ will resist this autoignition. It can also be gauged in terms of ignition delay, the time it takes for a fuel-air mixture to ignite, at a given temperature and pressure condition in the engine combustion chamber. A gasoline mixture is composed of various compounds and hydrocarbon classes, each contributing in varying degree to the net ignition delay time (IDT) of the fuel. Future fuel design will dictate fuel composition tailored to high octane demands of the engine [5, 6]. In this regard, it is necessary to quantify the effect of various hydrocarbon classes on ignition delay of the fuel, and therefore guide refiners for improved fuel quality based on distillation properties. Two sets of ON are used in characterizing a fuel: research octane number (RON) and motor octane number (MON) based on American Society for Testing and Materials (ASTM) standards D2699 and D2700, respectively [7, 8]. The difference between RON and MON is defined as octane sensitivity (OS) (=RON-MON). 
As $\mathrm{RON} / \mathrm{MON}$ were not able to accurately predict autoignition characteristics in modern engines due to the shift in pressure/temperature history from the standard Cooperative Fuel Research (CFR) engine, new metrics may be desirable. One such metric that has drawn attention recently is the octane index (OI); that takes into consideration of a physical operating condition in addition to the RON/MON of the fuel $[9,10]$. OI is defined as a weighted average of RON/MON:

$$
\begin{array}{r}
O I=(1-k) R O N+k M O N \\
O I=R O N-k(O S)
\end{array}
$$

Here, the linear weighting factor, $k$, indicates how far the operating condition is from the RON or MON condition. Many studies have shown that $k$ values in modern SI engines are approaching negative values. Hence, fuels with higher OS would be beneficial in modern SI engines due to higher OI [11-13].

Octane-on-demand (OoD) is another concept that aims to minimize vehicular carbon footprint, by using a high reactivity (low octane) gasoline during normal operation at low to medium loads and a low reactivity (high octane) gasoline fuel at high load knock-prone conditions [14, 15]. However, space and comfort-to-refuelling issues exist when considering dual-fuel concepts in passenger cars [16]. In this regard, on-board separation of a high octane fuel into varying octane components is a viable option [17]. One of the proposed methods of on-board separation depends on distillation of fuel into lighter and heavier components, which may correspond to high reactivity and low reactivity components, respectively. In such an application, the need for analyzing the octane behavior of each distillation cut is critical to the adoption of the technology. In the light of such importance, understanding the ignition behavior of distillation cuts provides a better understanding of the interaction between the physical and chemical properties of a gasoline fuel.

Transportation fuels such as gasolines are composed of several hundred different species $[18,19]$. Identification and quantification of such a large number of species are an enormous task. However, these species are in turn composed of a small number of functional groups that mostly determine fuel properties (ON [20], CN [21], sooting propensity [22], etc.). The IDT of a fuel is dependent on its chemical composition (namely, the functional groups) as shown by a number of works $[20,23]$. Though the sum total of the functional groups in gasoline is conserved in its distillate fractions, the functional groups in each of the fraction may interact with each other differently (either synergestically or antagonistically) and produce a combined effect that may not correlate linearly with that of the parent fuel. Studies on gasoline fractions enables an understanding of these interactions and their behavior in applications involving gasoline separated into different fractions based on boiling points (BPs) such as OoD. Analyzing these functional groups is a useful way to characterize such complex fuels. ${ }^{1} \mathrm{H}$ nuclear magnetic resonance (NMR) spectroscopy is a powerful tool that can identify and quantify various functional groups present in 
fuels like gasoline [24], diesel [21, 24], base oil [25], and heavy fuel oil [26, 27]. ${ }^{1} \mathrm{H}$ NMR spectra is represented using chemical shifts (usually between o-12 ppm) which is the resonant frequency of ${ }^{1} \mathrm{H}$ nuclei relative to a standard magnetic field. Molecular structure can then be diagnosed from the position and the number of chemical shifts recorded. A significant advantage of ${ }^{1} \mathrm{H}$ NMR spectroscopy is that different functional groups closely resembling in structure produce distinct signals which makes their analysis easy and quick.

The present work aims to couple a spinning band distillation column with an ignition quality tester (IQT) [28] to estimate the IDTs of separate volume fractions of various non-oxygenated gasolines [29] and two oxygenated certification gasolines. The observations are further correlated with the presence of specific hydrocarbon functional groups, based on NMR spectroscopic data. Hetzel [30] in 1936 investigated the ignition quality of diesel fractions with $\mathrm{CN}$ obtained with engine measurements. The diesel used in Hetzel's experiments [30] had a CN of 55 and was separated into 12 equal fractions. Recently, Burger et al. [31] measured the enthalpy of combustion and hydrocarbon family types (using mass spectrometric classification technique) of FACE gasoline fractions. Fuels for advanced combustion engines (FACE) gasolines are research grade fuels with specific target properties viz., RON and OS, such that various laboratories could evaluate fuels with consistent composition and properties set forth by the Coordinating Research Council (CRC) [32]. Classification of hydrocarbon family types in Burger et al. [31] was based on ASTM D2789 standard [31, 33], which characterizes different components in a hydrocarbon mixture into six types. The six types of classification based on ASTM D2789 standard are paraffins, monocycloparaffins, dicycloparaffins, alkylbenzenes, indanes and tetralines (grouped together), and naphthalenes. As many of the gasolines in our study contains olefins and classification in this work is based on PIONA (paraffins, iso-paraffins, olefins, naphthenes, and aromatics) a direct comparison between our results and the results in Burger et al. [31] was not performed. It was also explicitly stated in [31] that a direct quantitative comparison of the results based on ASTM D2789 method to other classification methods was not always possible. However, the ignition quality of the gasoline fractions were not obtained in their study. To the authors' best knowledge, this is the first work that investigates the ignition quality of gasoline fractions.

This study attempts to use volatility (physical property) and chemical functional groups (chemical property) to better understand fuel autoignition quality (physico-chemical kinetic property). Various boiling ranges can be correlated with the functional groups present in gasolines, which in-turn dictates the autoignition tendency or IDT of the fraction. The data presented could pave a way for future fuel design for better control over desired properties. 
In the present study, six FACE and two certification gasolines are fractionated; their imporant fuel properties are Table 1. Gasolines obtained from fractional distillation of crude oil in general do not contain oxygenates in appreciable amounts. However, oxygenates are added to gasoline feed stock to enhance its ON. The certification gasolines having oxygenates used in the present study are obtained from Coryton Advanced Fuels and Haltermann Solutions, whose properties are obtained from their respective certificates of analysis (COAs).

The gasoline distillates or cuts are obtained with a spinning band distillation system. The distillates obtained were then measured in a King Abdullah University of Science and Technology (KAUST) research-IQT (KR-IQT) at the standard derived cetane number (DCN) condition and at a low temperature condition (ignition delay time sensitivity (IDS) condition explained later) [34]. In addition, spectroscopic analysis of the distillate cuts were obtained with ${ }^{1} \mathrm{H}$ NMR spectroscopy to quantify the different hydrocarbon classes in each cut. Details on the distillation system, KR-IQT and NMR methodology are explained in the following subsections.

Table 1: Fuel properties

\begin{tabular}{lcccccccc}
\hline Fuel & $\begin{array}{c}\text { FACE A } \\
\text { gasoline }\end{array}$ & $\begin{array}{c}\text { FACE C } \\
\text { gasoline }\end{array}$ & $\begin{array}{c}\text { FACE F } \\
\text { gasoline }\end{array}$ & $\begin{array}{c}\text { FACE G } \\
\text { gasoline }\end{array}$ & $\begin{array}{c}\text { FACE I } \\
\text { gasoline }\end{array}$ & $\begin{array}{c}\text { FACE J } \\
\text { gasoline }\end{array}$ & $\begin{array}{c}\text { Coryton } \\
\text { gasoline }\end{array}$ & $\begin{array}{c}\text { Haltermann } \\
\text { gasoline }\end{array}$ \\
\hline RON & 83.5 & 84.7 & 94.4 & 96.8 & 70.3 & 71.8 & 97.5 & 91.0 \\
MON & 83.6 & 83.6 & 88.8 & 85.8 & 69.6 & 68.8 & 86.6 & 83.4 \\
Sensitivity & -0.1 & 1.1 & 5.6 & 11.0 & 0.7 & 3.0 & 10.9 & 7.6 \\
Density (kg/m ${ }^{3}$ ) & 685 & 691 & 707 & 761 & 687 & 741 & 741 & 748 \\
AFR stoic & 15.18 & 15.04 & 14.95 & 14.55 & 15.14 & 14.65 & 14.47 & 14.74 \\
H/C ratio & 2.29 & 2.19 & 2.12 & 1.84 & 2.26 & 1.91 & 1.78 & 1.97 \\
\hline Paraffins (v.\%) & 11.65 & 24.43 & 4.40 & 6.73 & 14.39 & 31.64 & 10.00 & 13.40 \\
iso-Paraffins (v.\%) & 85.99 & 69.73 & 67.56 & 38.43 & 74.54 & 33.64 & 38.50 & 33.70 \\
Olefins (v.\%) & 0.21 & 1.27 & 9.42 & 8.11 & 6.35 & 0.60 & 10.00 & 6.80 \\
Naphthenes (v.\%) & 1.61 & 0.36 & 10.98 & 11.52 & 3.30 & 2.29 & 5.10 & 15.20 \\
Aromatics (v.\%) & 0.38 & 3.92 & 7.72 & 33.63 & 1.15 & 31.69 & 32.40 & 22.70 \\
Oxygenates (v.\%) & - & - & - & - & - & - & 4.00 & 8.20 \\
\hline
\end{tabular}

\subsection{Spinning band distillation system}

The gasoline cuts are obtained with a spinning band distillation system (B/R Instrument Corp., 36-10o high efficiency distillation system), as schematically shown in Fig. S1. The device separates liquids with similar BPs with the use of a helical spinning Teflon band. The vapors of the test fuel generated from the electrically heated round bottom flask condense on externally cooled glass coil. The spinning helical Teflon band creates close contact between the condensing liquid and rising vapor. The spinning band refreshes this dynamic process that results in liquid vapor 
equilibration that enables effective separation of liquids with similar BPs. To ensure temperature uniformity of the fluid in the boiling flask, a magnetic stirrer drive was placed beneath the aluminum jacket with a magnetic stirrer in the fluid. The condensates separated are then collected in various receivers as seen in Fig. S1. For each test, $1 \mathrm{~L}$ of fuel is placed in the boiling flask and $100 \mathrm{~mL}$ of fuel ( $10 \%$ in volume) is collected in each receiver. The device has 8 receivers, thereby 8 cuts and the remaining residue ( $20 \%$ in volume) in the boiling flask provided 9 cuts. More details on the device are available in [35].

The distillation curves of all the gasoline cuts obtained with the spinning band distillation system are shown in Fig. 1 as a function of the vapor temperature.

\subsection{KAUST-research ignition quality tester}

The KR-IQT is a constant volume combustion chamber pressurized to $21.37 \pm 0.1$ bar and is heated to a standard temperature prescribed by the ASTM D689o standard [28]. The results presented below are the average IDT of 32 injections and error bars indicate standard deviation of the readings. More details on the KR-IQT are available in [35, 36].

In addition to IDT measurements at the ASTM D689o standard [28] condition, IDTs were also measured at a lower temperature, which is referred to the IDS temperature to estimate RON and MON of various gasoline cuts. In recent studies [34, 37], the IDT measured at the standard condition could estimate RON and the IDT measured at the IDS temperature enabled the prediction of OS of the fuel, thus MON.

The RON of various gasoline cuts are predicted with the DCN-RON correlation proposed in [37] as

$$
R O N=-293\left(\frac{D C N}{100}\right)^{2}-52\left(\frac{D C N}{100}\right)+114.1
$$

The IDS temperature was defined by adjusting the chamber temperature such that an average of $3 n$-heptane runs provides an IDT of $7.56 \pm 0.04 \mathrm{~ms}$ (corresponding to twice of the IDT at the standard temperature). The IDS was defined as the ratio between IDTs of non-primary reference fuel (PRF) and PRF at the IDS temperature that have matching DCN at the standard temperature as given in Eq. (3). With the IDT measured at the IDS temperature, the OS can be obtained with Eq. (4). From the predicted RON and OS, MON is estimated as MON=RON-OS. More details on the concept of IDS are available in [34, 35].

$$
\begin{gathered}
I D S=\frac{I D T_{l, n o n-P R F}}{I D T_{l, P R F}} \Leftrightarrow D C N_{\text {non-PRF }} \approx D C N_{P R F} \\
\text { OS }=\frac{34 \ln (I D S)}{[0.84+\ln (I D S)]}
\end{gathered}
$$



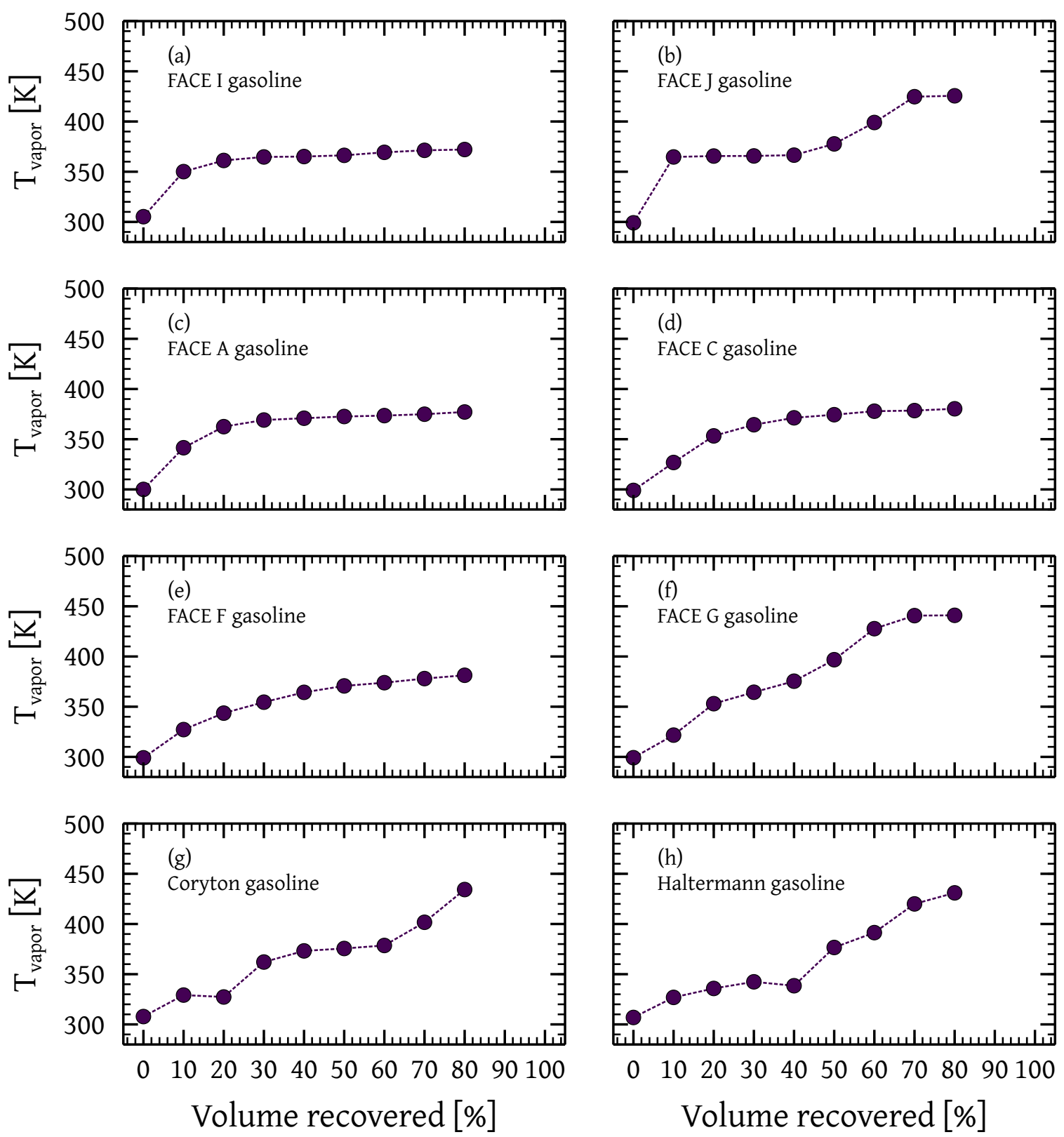

Figure 1: Comparison of distillation curves (vapor temperature) for various gasolines obtained with spinning band distillation system. 


\subsection{Nuclear magnetic resonance (NMR) spectroscopy}

NMR spectra were acquired using NMR spectrometer (Bruker 70o MHz AVANACIII) equipped with Bruker CPTCI multinuclear CryoProbe (Bruker BioSpin). Details on the sample preparation, signal recording, and assignment of chemical shifts in ${ }^{1} \mathrm{H}$ NMR measurements are available in the Supplementary Material.

\subsection{Determining functional groups}

Gasolines are mostly composed of paraffins ( $n$ - and iso-), olefins, naphthenes, aromatics, and oxygenates (usually as added ethanol). The above hydrocarbon classes can be disassembled into the following seven functional groups, namely, paraffinic $\mathrm{CH}_{3}$ groups, paraffinic $\mathrm{CH}_{2}$ groups, paraffinic $\mathrm{CH}$ groups, olefinic $\mathrm{CH}=\mathrm{CH}_{2}$ groups, naphthenic $\mathrm{CH}-\mathrm{CH}_{2}$ groups, aromatic $\mathrm{C}-\mathrm{CH}$ groups, and ethanolic $\mathrm{OH}$ groups. Each of these functional groups produces a distinct peak in the ${ }^{1} \mathrm{H}$ NMR spectra at a characteristic region and an integration allows for a quantification. The ${ }^{1} \mathrm{H}$ chemical shift assignments used in the present work are reported in Table $\mathrm{S}_{1}$, taken from Abdul Jameel et al. [21]. The ${ }^{1} \mathrm{H}$ NMR spectra identifies and quantifies only the ${ }^{1} \mathrm{H}$ nuclei appearing in these functional groups. The quantity of the functional group in the sample are then calculated by adding the contribution of carbon atoms. For example, the relative quantity of paraffinic $\mathrm{CH}_{2}$ groups ( $\mathrm{wt} \%$ ) can be calculated by multiplying the fraction of ${ }^{1} \mathrm{H}$ nuclei that gives rise to paraffinic $\mathrm{CH}_{2}$ peaks (from NMR spectra) with the groups molecular weight (i.e., 14) and then dividing the result by the number of ${ }^{1} \mathrm{H}$ nuclei in the group (i.e., 2). The quaternary aromatic carbons that do not show up in the ${ }^{1} \mathrm{H}$ NMR spectra are calculated by the knowledge of the hydrocarbon groups in $\alpha$ position to the ring. The procedure and equations to calculate the above functional groups are discussed in detail elsewhere [20, 21].

\section{RESULTS AND DISCUSSION}

This section details a comparison between the compositional effects on the reactivity of fuels based on ON range. The distillation curves are the manifestation of the compounds, and their functional groups present in the different cuts. The same functional groups affect the reactivity of the cut; hence, all discussions are made from the perspective of functional groups. All the IDT data are plotted with respect to liquid temperature in the boiling flask of the spinning band distillation system. The spacing of the various cuts in the figure indicates the separation in the BP of the respective cuts. The ${ }^{1} \mathrm{H}$ NMR spectra of full blend gasoline and their respective cuts are available in Figs. S2 to S9. 


\subsection{High reactivity gasolines}

FACE I and J gasolines are characterized as high reactivity gasolines owing to their low ONs (RON of 70.3 and 71.8, respectively) compared to commercial gasolines. Such high reactivity gasolines are potential fuels for PPCI/gasoline compression ignition (GCI) engine applications [38-42]. The distillation curves (liquid temperature) of FACE I and J gasolines obtained with the spinning band distillation system are shown in Figs. $1(a)$ and $1(b)$. From the figure, it can be observed that how different compositions given in FACE I and J gasolines influence the BPs of different cuts of gasoline, particularly in the back end (final boiling range). The presence of aromatics in FACE J gasoline (31.7 vol\%) causes wider spread in BP due to their larger molecular weights, which is evident from the higher final boiling point (FBP) of FACE J gasoline.

The ignition quality of these various cuts obtained with the spinning band distillation system was measured with the KR-IQT at the standard DCN condition (high temperature) and the IDS condition (low temperature) [34]. Figure 2 shows the IDTs of various cuts of FACE I and J at DCN and IDS conditions along with the various functional groups present in the full blend and each cut. The IDTs of various cuts of FACE I gasoline at the DCN condition in Fig. 2(a) show that cut 1 has the longest IDT due to the higher content of paraffinic $\mathrm{CH}_{3}$ groups along with the fact that lighter paraffinic hydrocarbons (having lower BPs) having longer IDTs. FACE I gasoline is mostly paraffinic (96.5 $\mathrm{wt} \%$ ) and the quantities of olefinic, naphthenic, and aromatic groups (3.5 wt\%) are very small as observed in Fig. 2(e). The ignition quality of such fuels depends on the degree of methyl substitution. The IDT of a paraffinic fuel increases with the increase in the paraffinic $\mathrm{CH}_{3}$ groups as experimentally demonstrated in a constant volume combustion chamber (CVCC) using the mixtures of $\mathrm{C}_{16}$ isomers (n-hexadecane, 2,6,10-trimethyltridecane, and 2,2,4,4,6,8,8-heptamethylnonane) [43]. 
FACE I gasoline
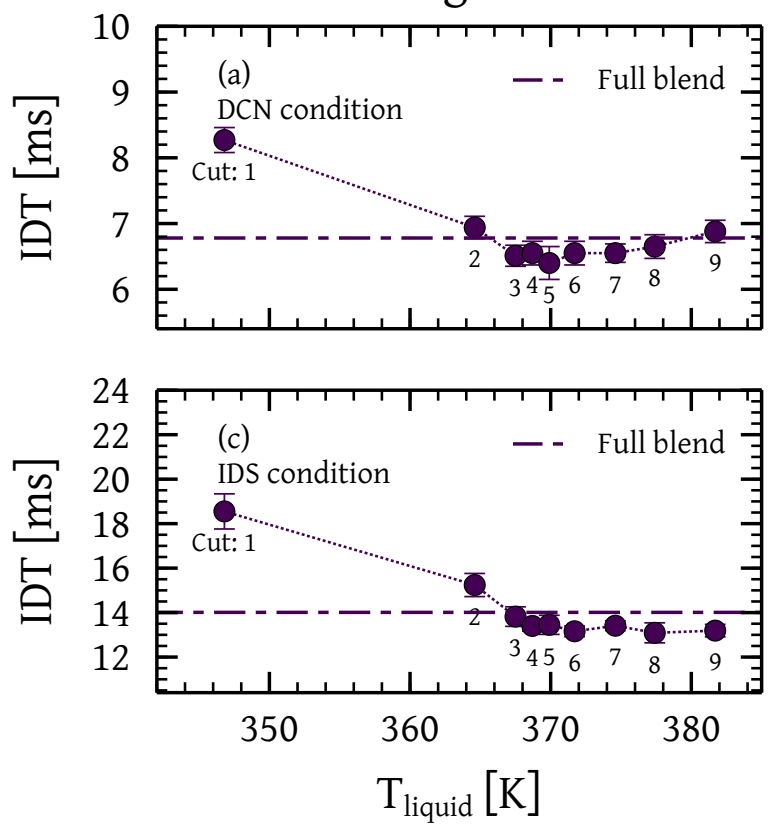

(e)

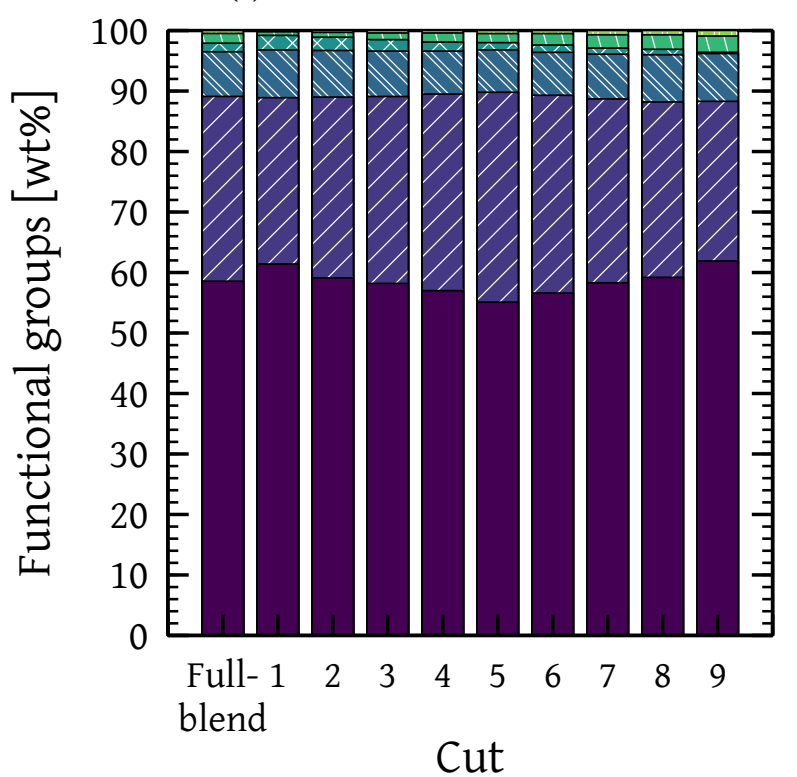

FACE J gasoline
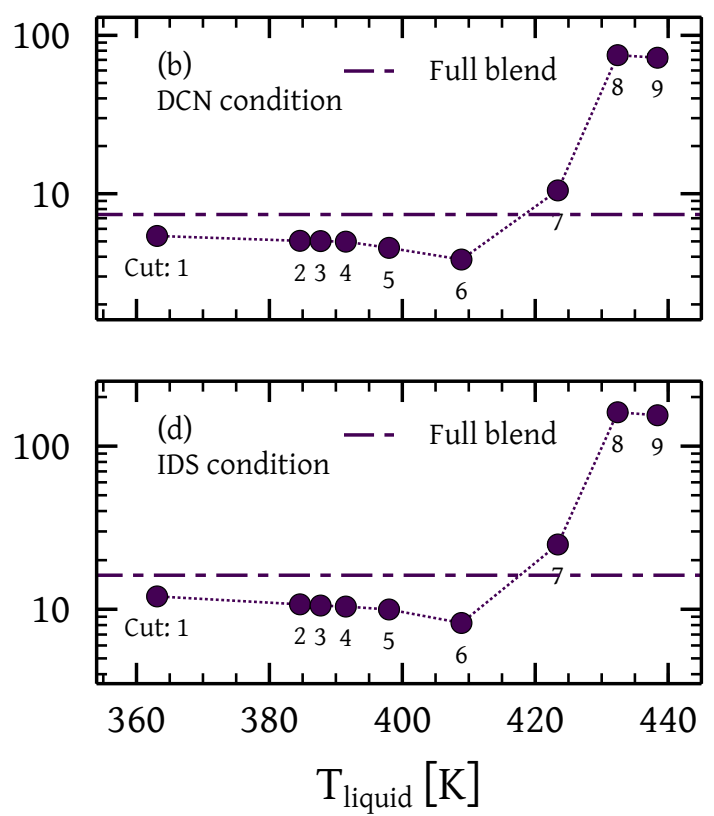

(f)

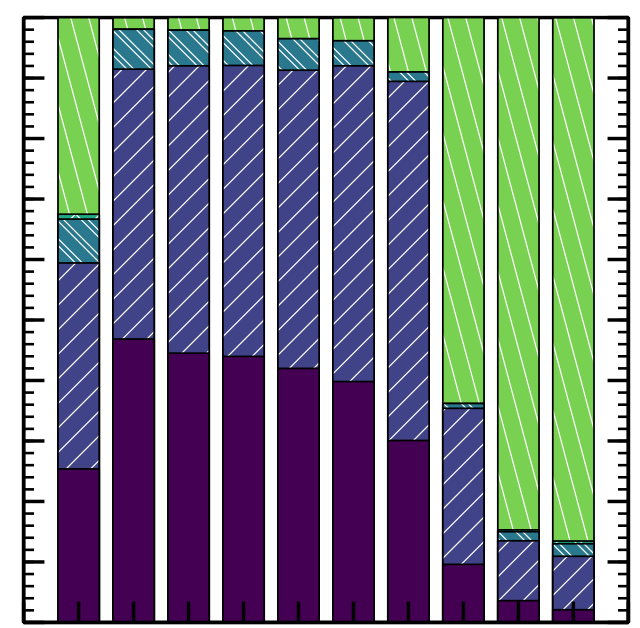

Full- $1 \quad 2 \quad 3 \quad \begin{array}{lllllll}4 & 2 & 5 & 6 & 7 & 8 & 9\end{array}$ blend

Cut

\begin{tabular}{|c|c|c|c|c|}
\hline $\begin{array}{l}\text { Paraffinic } \mathrm{CH}_{3} \\
\text { Paraffinic } \mathrm{CH}_{2} \\
\text { Paraffinic } \mathrm{CH}\end{array}$ & $\begin{array}{l}\square X \\
\square \\
\square\end{array}$ & $\begin{array}{l}\text { Olefinic } \mathrm{CH}=\mathrm{CH}_{2} \\
\text { Naphthenic } \mathrm{CH}-\mathrm{CH}_{2} \\
\text { Aromatic } \mathrm{C}-\mathrm{CH}\end{array}$ & $\begin{array}{l}\text { Paraffinic } \mathrm{CH}_{3} \\
\text { Paraffinic } \mathrm{CH}_{2} \\
\text { Paraffinic } \mathrm{CH}\end{array}$ & $\begin{array}{l}\text { Naphthenic } \mathrm{CH}-\mathrm{CH}_{2} \\
\text { Aromatic } \mathrm{C}-\mathrm{CH}\end{array}$ \\
\hline
\end{tabular}

Figure 2: IDT of high reactivity gasolines for FACE I (left panel) and FACE J (right panel) gasolines at (a), (b) DCN and (c), (d) IDS conditions, and functional groups present in various cuts (e), (f). 
Abdul Jameel et al. [21] also showed an increase in the IDT of an ' $n$-heptane and iso-octane' mixture with the increase in the paraffinic $\mathrm{CH}_{3}$ groups. Methyl substitution also inhibited low temperature chain branching reactions [44]. For heavier cuts (i.e., cuts 2 to 6), the IDT reduces as the paraffinic $\mathrm{CH}_{2}$ groups increase slowly. For $n$-paraffins and iso-paraffins, increasing the chain length (i.e., increasing paraffinic $\mathrm{CH}_{2}$ groups) results in a higher reactivity thereby shortening the IDT. This trend is observed until cut 6, after which the IDT starts increasing due to heavier components in FACE I gasoline such as aromatics and naphthenes but their fraction is low to cause any significant increase in IDT. The IDT of full blend FACE I gasoline at the DCN condition is $6.78 \mathrm{~ms}$ (Fig. 2(a)).

The IDTs of various cuts of FACE J gasoline are shown in Figs. 2(b) and 2(d) at the DCN and IDS conditions, respectively. Note the IDTs for FACE J gasoline are plotted on a logarithmic-scale (as compared with linear-scale for FACE I gasoline), due to a wide spread in their IDTs. Similar to FACE I gasoline, the IDT of cut 1 is slightly longer than cuts (2-6), due to higher methyl substitutions, as seen in Fig. 2(f). The paraffinic $\mathrm{CH}_{3}$ groups progressively decrease for the cuts 2-6 with increasing chain lengths (paraffinic $\mathrm{CH}_{2}$ groups). For cuts 8 and 9, very long IDTs are observed because of the existence of large quantities of aromatic $\mathrm{C}-\mathrm{CH}$ groups present in these cuts. Aromatic $\mathrm{C}-\mathrm{CH}$ groups have a more prominent effect on the IDT of a fuel compared to other paraffinic, olefinic, and naphthenic groups and tend to increase the IDT significantly [21]. FACE J gasoline has $32.5 \mathrm{wt} \%$ of aromatic groups, the largest of all FACE gasolines analyzed here. The IDT of the full blend FACE J gasoline at the DCN condition is 7.39 ms (Fig. 2(b)).

The IDTs of FACE I gasoline cuts at the IDS are observed to decrease with increase in cut number. The IDT of cut 9 at the IDS condition is observed to be even lower than the average, while cut 9 at the DCN condition has higher IDT than the average. However, in general, the trends in the variation of IDT at the IDS condition of various FACE gasoline cuts are observed to be similar to the trends observed at DCN condition with IDT being longer.

\subsection{Mid-range octane gasolines}

Next, the gasolines with $\mathrm{RON} / \mathrm{MON}$ in the range of 83.5-84.0, FACE A and $\mathrm{C}$ gasoline, are analyzed. The distillation curves of FACE A and $\mathrm{C}$ gasolines are similar (Figs. $1(\mathrm{c})$ and $\mathrm{I}(\mathrm{d})$ ). However; their compositions are quite different in terms of, especially, the amount of $n$ - and iso-paraffins. FACE A gasoline, by design, has a higher composition of iso-paraffins indicated by its higher paraffinic $\mathrm{CH}$ groups (25.1 $\mathrm{wt} \%$ ), whereas FACE C gasoline contains only $9.5 \mathrm{wt} \%$ of paraffinic $\mathrm{CH}$ groups. Figure 3 shows the ignition quality of FACE A gasoline cuts, which had fairly similar IDTs in all the cuts; this is because aromatic $\mathrm{C}-\mathrm{CH}$ groups, with the ability to significantly offset the IDTs of a cut are negligible in FACE A gasoline. 
FACE A gasoline
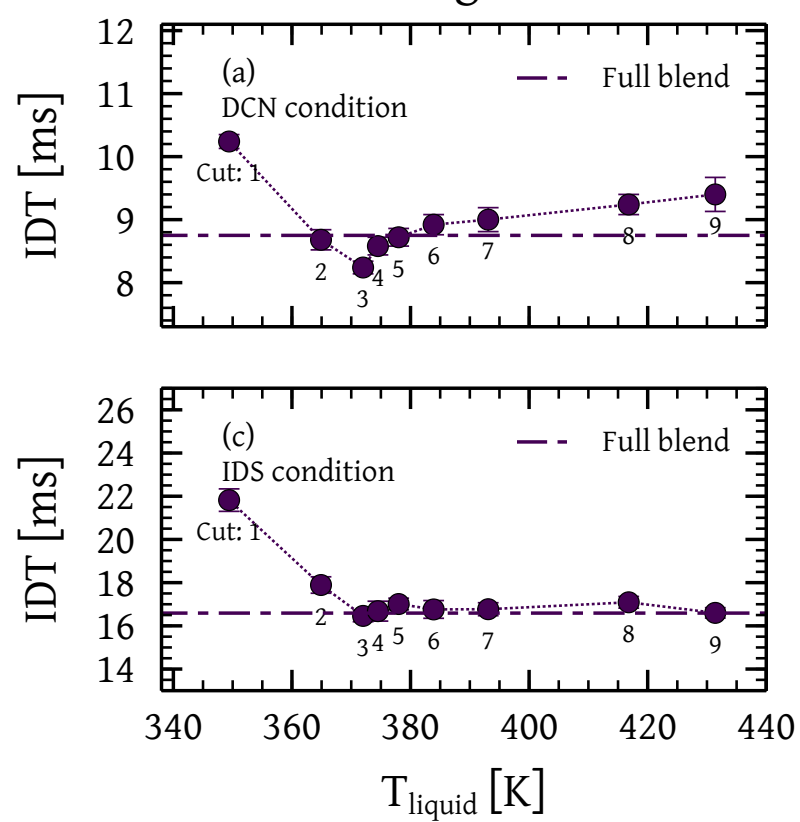

(e)

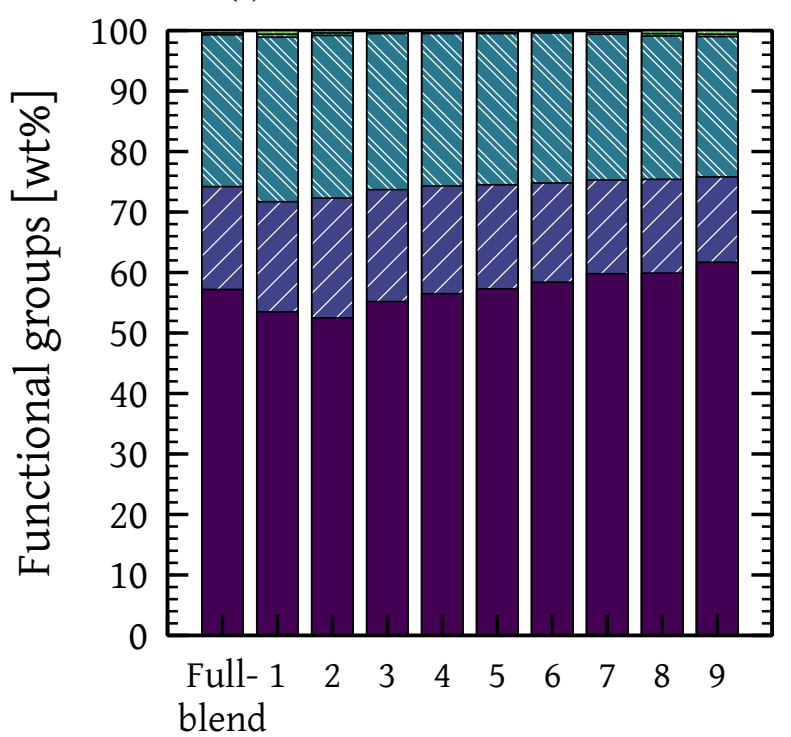

Cut
FACE C gasoline
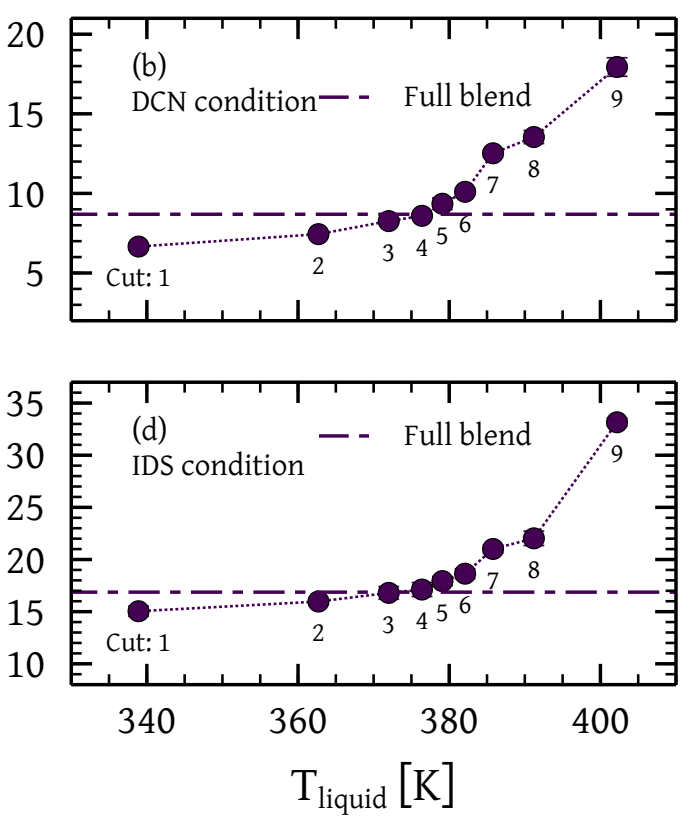

(f)

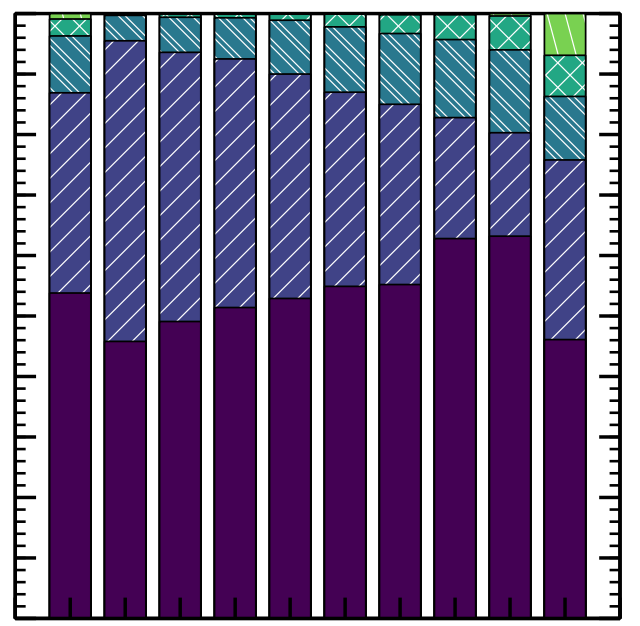

$\begin{array}{lllllllll}\text { Full- } 1 & 2 & 3 & 4 & 5 & 6 & 7 & 8 & 9\end{array}$ blend

Cut

\footnotetext{
Paraffinic $\mathrm{CH}_{3}$

$\square$ Paraffinic $\mathrm{CH}_{2}$ Paraffinic $\mathrm{CH}$
$\triangle$ Naphthenic $\mathrm{CH}-\mathrm{CH}_{2}$ Aromatic $\mathrm{C}-\mathrm{CH}$

Paraffinic $\mathrm{CH}_{3}$ Paraffinic $\mathrm{CH}_{2}$ Paraffinic $\mathrm{CH}$

Figure 3: IDT of mid-range octane gasolines for FACE A (left panel) and FACE C (right panel) gasolines at (a), (b) DCN and (c), (d) IDS conditions, and functional groups present in various cuts (e), (f). 
Cut 1 of FACE A gasoline has relatively longer IDT than the other cuts, mostly because it has higher paraffinic $\mathrm{CH}$ content compared to the other cuts. Generally, the IDT of a mixture increases with an increase in the paraffinic $\mathrm{CH}$ groups (branching), as experimentally demonstrated by Abdul Jameel et al. [21] for blends comprising of $n$-heptane, iso-octane, 1 -hexene, and cyclohexane. This is also seen in the FACE $\mathrm{C}$ gasoline cuts, where the paraffinic $\mathrm{CH}$ groups increase steadily from cut 1 to 8 , while simultaneously increasing the IDT of the cuts. Branching reduces the average chain length and smaller chain paraffins are observed to have longer IDT due to their low reactivities. The cut 9 of FACE $\mathrm{C}$ gasoline has lower paraffinic $\mathrm{CH}$ groups compared to cut 8 , and yet has a higher IDT because of its higher aromatic content. FACE C gasoline has $0.9 \mathrm{wt} \%$ of aromatic $\mathrm{C}-\mathrm{CH}$ groups, most of which shows up in cut 9. The IDTs of cuts 2 to 8 of FACE A gasoline are shorter than FACE C gasoline due to the higher paraffinic $\mathrm{CH}_{2}$ groups. FACE A gasoline has a higher branching index [21] of 0.42 compared to FACE C gasoline of 0.31 .

The IDTs of FACE C gasoline cuts increase monotonically at the DCN condition (Fig. 3(b)). Similar trends are observed at the IDS condition. But differences are observed in the IDTs of FACE A gasoline at the DCN and IDS conditions, where cut 9 is observed to be more reactive at the IDS condition compared to the preceding cut. However, at the DCN condition, cut 9 is less reactive than the preceding cut. Estimations of the RON/MON, as shown later, indicate that cut 9 is observed to have negative OS value. For many reasons this could be attributed to the presence of 3,3,5-trimethylheptane. The BP (= 429 K [45]) of 3,3,5-trimethylheptane corresponds to the boiling range of cut $9 \approx 430 \mathrm{~K}$; the highly branched structure evident from the functional group distribution, and as will be shown later the estimated RON/MON, is close to the nominal RON/MON of 86.5/88.7 obtained from [46].

\subsection{High octane gasolines}

Because of their high ONs (RON/MON in the range of 85.8-96.8), FACE F and $\mathrm{G}$ gasolines are representative of commercial gasolines. It can be observed from Fig. $\mathrm{I}(\mathrm{f})$ that FACE $\mathrm{G}$ gasoline had the widest spread in BPs.

Figure 4 shows the ignition quality and the functional group distribution of the full blend FACE F and G gasolines and their cuts. Both fuels have an appreciable distribution of the various functional groups except olefinic $\mathrm{CH}=\mathrm{CH}_{2}$ groups. Cut 1 of FACE F gasoline has longer IDT than cuts 2-8 due to its high paraffinic $\mathrm{CH}$ content and low paraffinic $\mathrm{CH}_{2}$ content. Proceeding from cut 1 to 8 , the paraffinic $\mathrm{CH}$ groups decrease steadily, whereas the paraffinic $\mathrm{CH}_{2}$ groups keep on increasing slightly. The quantity of aromatic $\mathrm{C}-\mathrm{CH}$ groups increases slightly from cut 1 (1.1 $\mathrm{wt} \%)$ to cut $8(3.9 \mathrm{wt} \%)$ and suddenly increases to $26.8 \mathrm{wt} \%$ in cut 9 , which is the reason for its high IDT. For FACE gasoline, cut 9 has IDT longer than cut 1 at the DCN 
condition. However, at the IDS condition the IDT of cut 9 is shorter than the cut 1 . This could be attributed to the higher IDS of aromatics.

The IDT of FACE G gasoline cuts $1-6$ at the DCN condition follows a trend similar to FACE F gasoline cuts. However, the cuts $7-9$ of FACE gasoline exhibit behavior not observed for other gasolines used in the present study. For cuts 7-9 of FACE G gasoline, the IDTs have large values for cuts 7 and 8 and then the IDT decreases drastically for the cut 9. Note that the IDTs of FACE G gasoline cuts are plotted on a logarithmic-scale. The drastic reduction in IDT for cut 9 of FACE G gasoline could be attributed to the presence of long chain alkanes (isomers of decane and aromatics with $\mathrm{C}_{2}-\mathrm{C}_{4}$ alkyl substitutions, cf. COA in Supplpementary Material), as indicated by the higher paraffinic $\mathrm{CH}_{2}$ groups in Fig. $4(\mathrm{f})$. 
FACE F gasoline
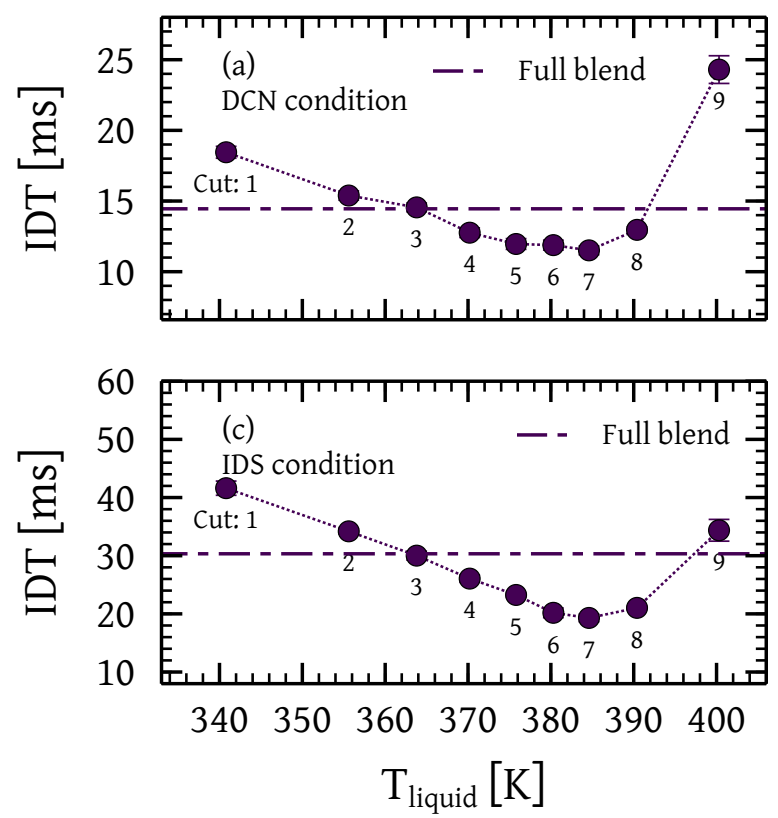

(e)

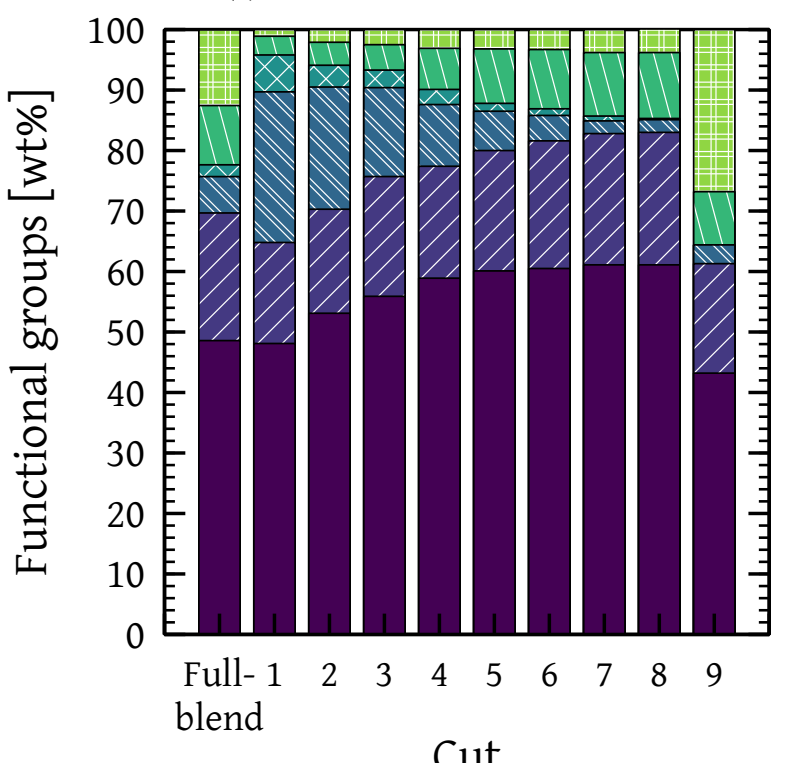

Cut
FACE G gasoline
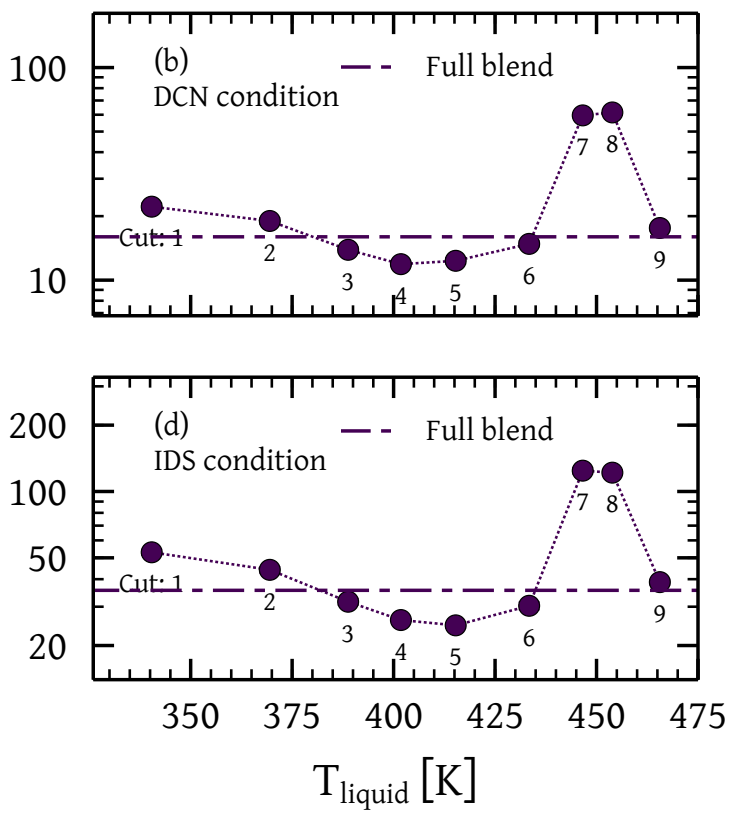

(f)

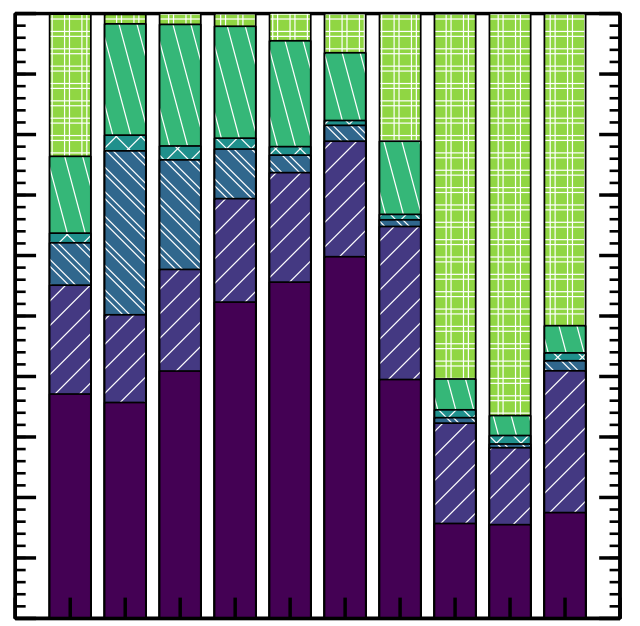

$\begin{array}{lllllllll}\text { Full- } 1 & 2 & 3 & 4 & 5 & 6 & 7 & 8 & 9\end{array}$ blend

Cut

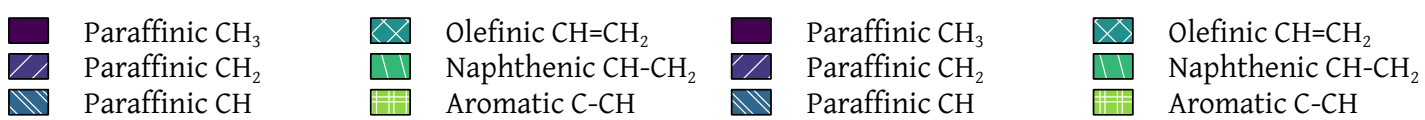

Figure 4: IDT of high octane gasolines for FACE F (left panel) and FACE G (right panel) gasolines at (a), (b) DCN and (c), (d) IDS conditions, and functional groups present in various cuts (e), (f). 


\subsection{Oxygenated certification gasolines}

The influence of oxygenates (ethanol in this case) in the certification fuels of Coryton and Haltermann gasolines is analyzed. The distillation curves (Figs. $I(g)$ and $1(h)$ ) show similar trends with a widespread in their BPs. The IDTs and functional groups in Coryton and Haltermann gasolines are shown in Fig. 5. Note that both the IDT scales are logarithmic. Coryton gasoline has a high quantity of aromatic groups (34.7 $\mathrm{wt} \%)$ along with an appreciable naphthenic $\mathrm{CH}-\mathrm{CH}_{2}$ content $(7.6 \mathrm{wt} \%)$, whereas Haltermann gasoline has a lower aromatic $\mathrm{C}-\mathrm{CH}$ content $(21.1 \mathrm{wt} \%)$ and a higher naphthenic $\mathrm{CH}-\mathrm{CH}_{2}$ content (10.8 $\left.\mathrm{wt} \%\right)$. Both fuels contain ethanolic $\mathrm{OH}$ groups as observed from the peak in the ${ }^{1} \mathrm{H}$ NMR spectra between 3.6-3.8 ppm (Figs. S8 and S9). A unit $\mathrm{wt}_{\mathrm{t}} \%$ increase in the ethanolic $\mathrm{OH}$ groups has a greater impact on fuel ON than any other groups [20], as ethanol acts as a radical scavenger leading to the reduction of fuel reactivity and its low temperature heat release (LTHR) characteristics [47]. Figure 5(a) shows the IDTs of Coryton gasoline and its cuts at the DCN condition. Unlike other gasolines tested here, cut 1 of Coryton gasoline has an appreciable amount of aromatic $\mathrm{C}-\mathrm{CH}$ groups together with ethanolic $\mathrm{OH}$ groups, resulting in relatively short IDT. The IDT increases for cuts $2-7$ and for cuts 8 and 9 the IDT are observed be long (note the logarithmic-scale) due to very high aromatic contents 51.7 and $61.0 \mathrm{wt} \%$ of aromatics for cuts 8 and 9, respectively.

The Haltermann gasoline cuts are observed to show increasing IDT for the cuts 1-4. However, for the remaining cuts the IDT progressively decreases. The increase in the IDT for cuts $1-4$ is mostly due to the increase in the ethanolic $\mathrm{OH}$ groups as seen in Fig. 5(f). For the later cuts 5-9, the increase in IDT is not observed even with the increase in aromatic $\mathrm{C}-\mathrm{CH}$ content. This may be because the later cuts possess a fair quantity of all the different functional groups and the IDT of each cut is due to the net effect of the complex interaction between these individual groups.

The IDTs at the IDS condition are observed to be similar to those at the DCN condition for both Coryton and Haltermann gasolines. 
Coryton gasoline
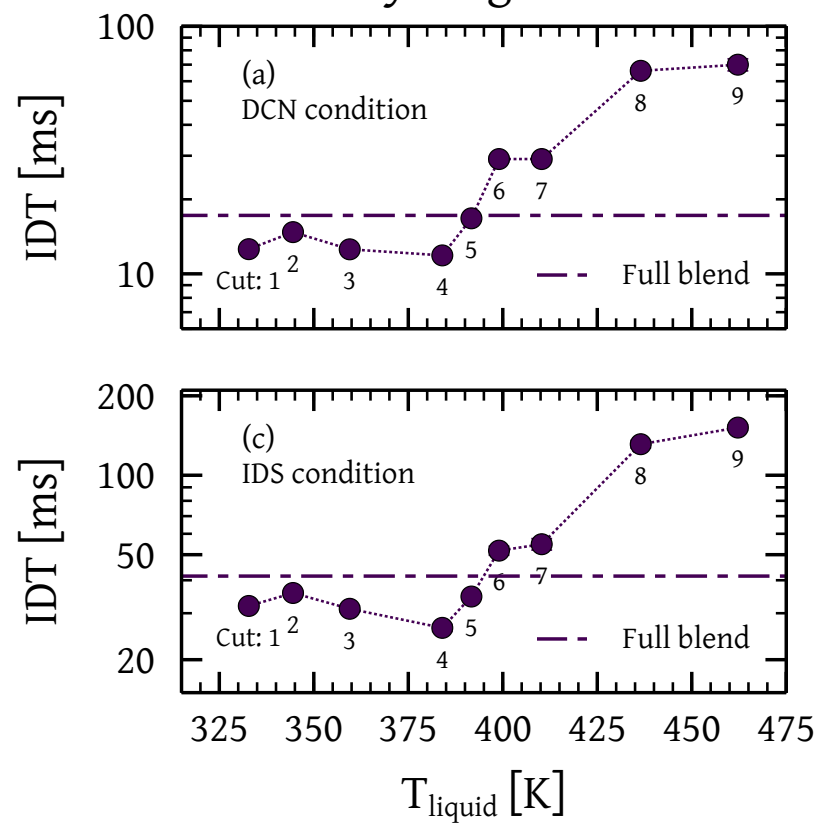

(e)

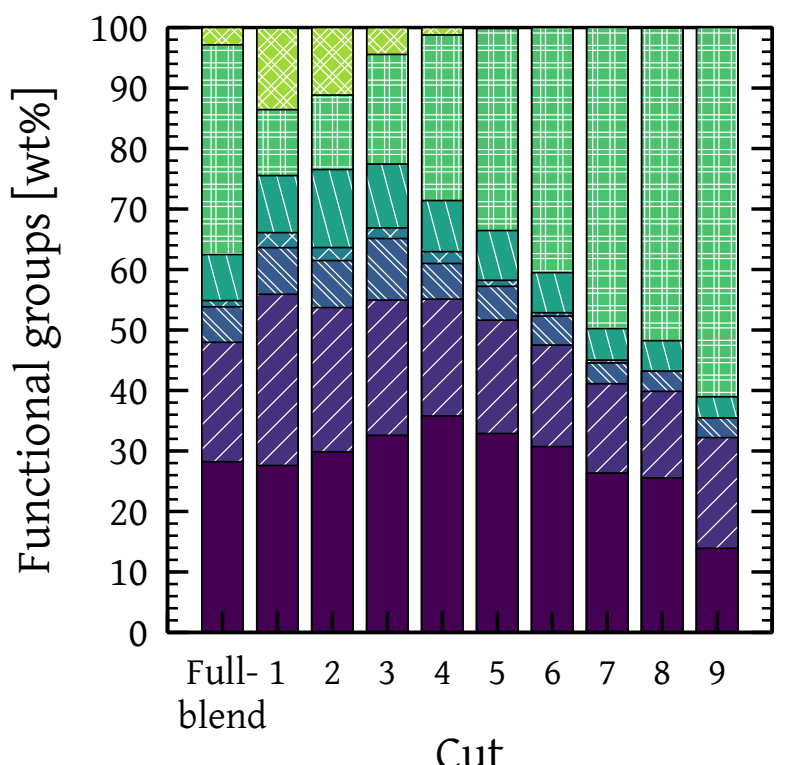

Haltermann gasoline
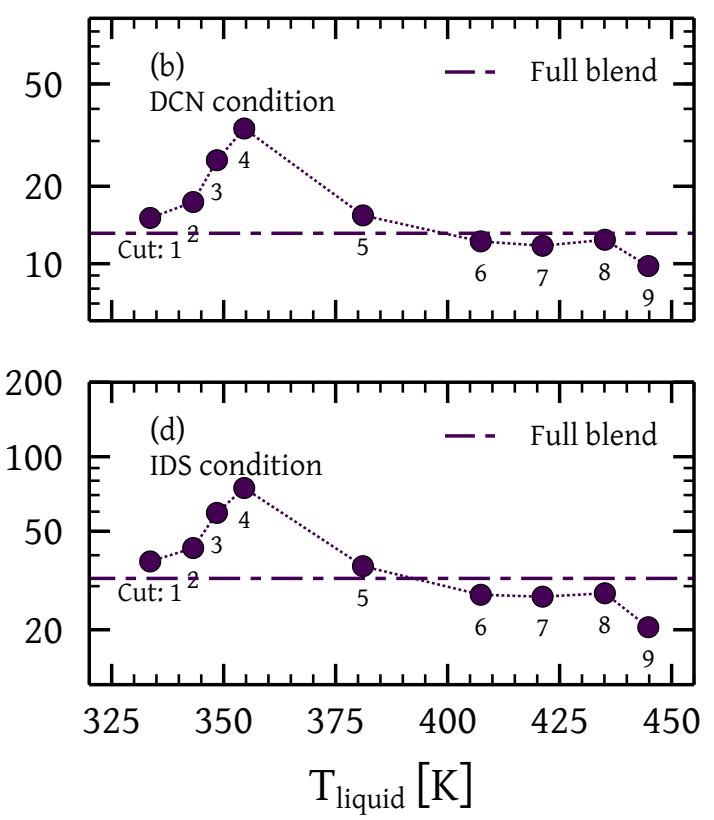

(f)

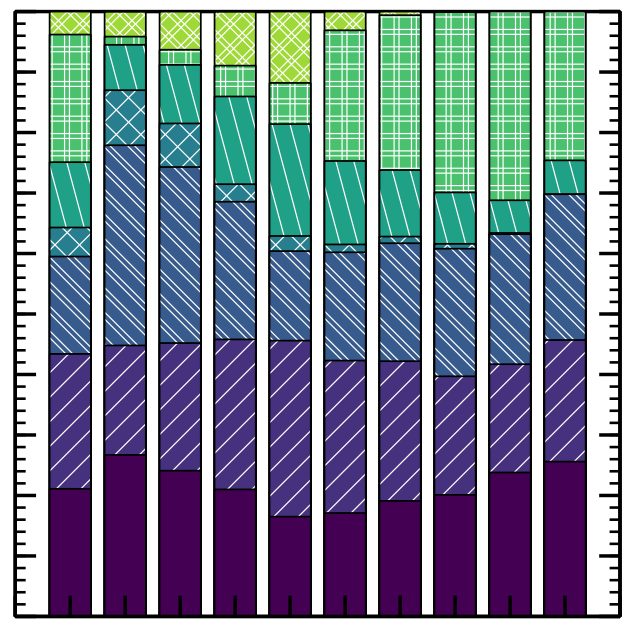

$\begin{array}{lllllllll}\text { Full- } 1 & 2 & 3 & 4 & 5 & 6 & 7 & 8 & 9\end{array}$ blend

Cut
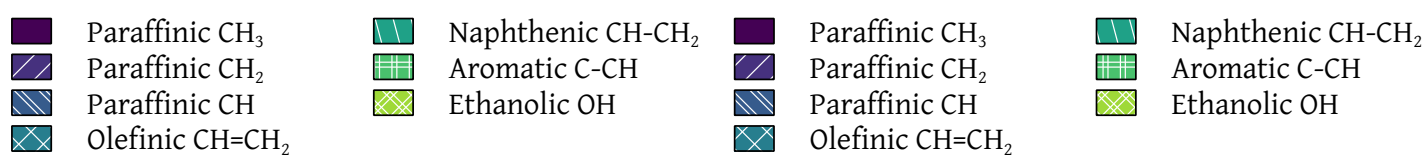

Figure 5: IDT of oxygenated certification gasolines for Coryton (left panel) and Haltermann (right panel) gasolines at (a), (b) DCN and (c), (d) IDS conditions, and functional groups present in various cuts (e), (f). 


\subsection{Effects of boiling points on physical delay times}

Numerous research has been published in recent years indicating the importance of fuel's physical properties on combustion, abnormal combustion events such as knock, pre-ignition and superknock, cold-start conditions, emission characteristics, and surrogate fuel formulations [48-57]. Many of the studies indicate the importance of distillation curve characteristics on fuel spray development and fuel stratification in direct injection (DI) engines.

As the IQT uses a liquid fuel injection system, the total IDT is a combination of physical and chemical delay times $[35,58]$. The physical delay times (PDTs) of various gasoline cuts were obtained with a point of inflection (POI) approach that is based on the change of curvature of the IQT pressure trace that occurs after the start of injection (SoInj); more details on the approach is described in [59]. The relative contribution of the PDTs to the total IDTs of each gasoline cut at both conditions (DCN and IDS) is shown in Fig. 6. For all the fuels studied in this work, the relative contribution of the PDTs to the IDT was less than $50 \%$. The largest contribution of PDT was observed for FACE J gasoline cut 6 , which has also the lowest predicted ONs as shown in the next subsection. The PDTs of all fuels are more or less consistent with marginal increase for heavier cuts, but all PDTs were less than $2.6 \mathrm{~ms}$ as shown in Fig. Sio. However, depending on the total IDT including the chemical delay times, their contribution varies for each cut.

For each gasoline, the influence of BPs on the PDT contribution to IDT is minimal and reflective of an inverse variation of the IDT. For high reactivity gasolines with low aromatic content, the importance of PDTs increases steadily due to the increasing PDTs and reducing IDTs for heavier cuts (cf. Figs. 2 and S10). The light cuts of these gasolines containing appreciable amount of aromatics have appreciable physical process contribution, but heavier cuts are predominantly influenced by the chemical processes as observed in Fig. 6 (b). Similar observations can be made for mid-range octane gasolines, for gasolines with considerable amount of aromatics the relative contribution of physical processes reduce for heavier cuts containing aromatics. With increasing ONs, i.e., for high octane gasolines and oxygenated certification gasolines, the influence of physical processes on ignition also reduces. This could be attributed to the consistent PDTs for different gasolines and their cuts and increasing IDTs for increasing ONs. 

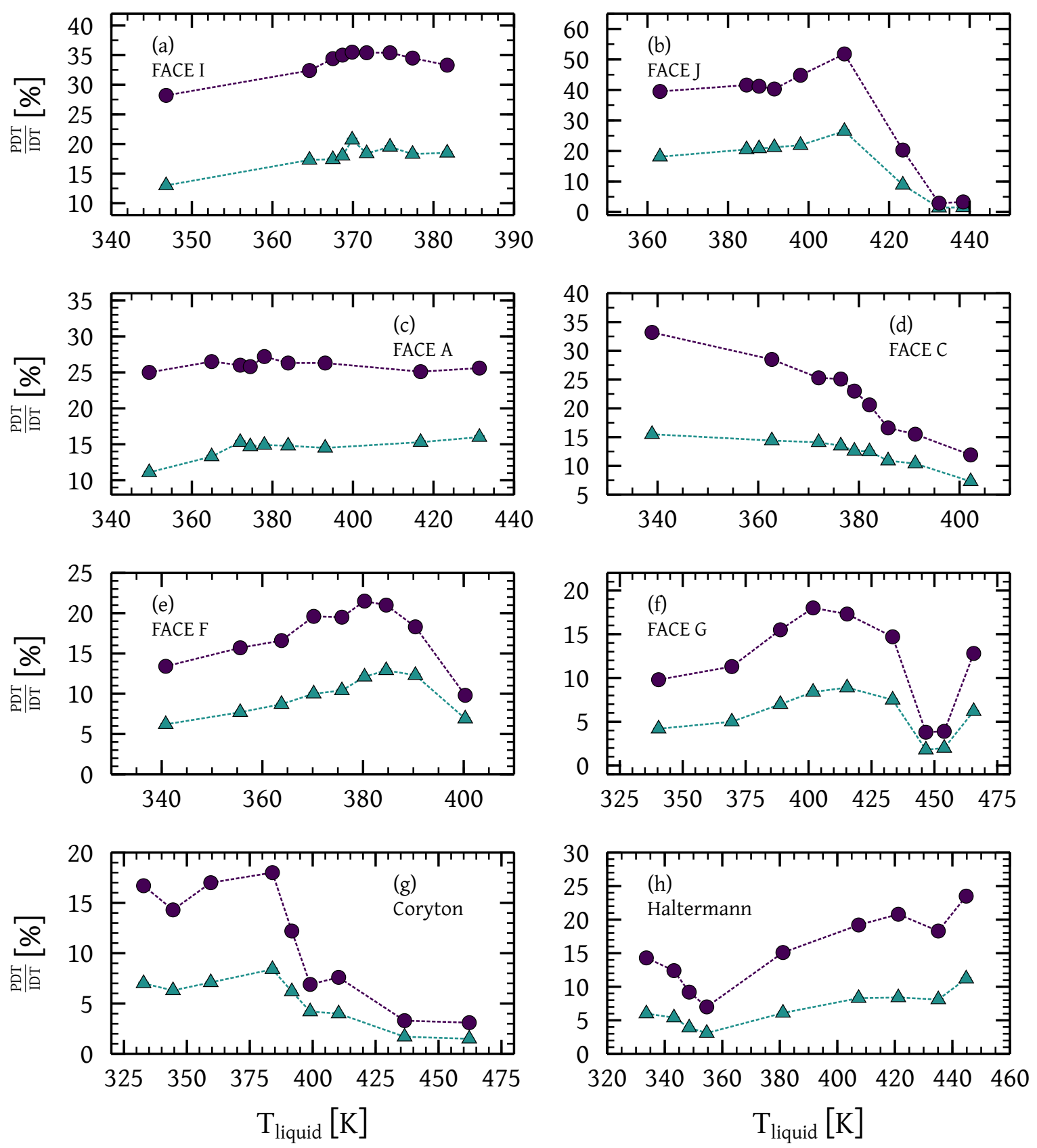

DCN condition - - $\overline{\underline{X}}-\cdot \quad$ IDS condition

Figure 6: Comparison of the relative contribution of the PDTs of various fractional cuts in terms of $T_{\text {liquid }}$ (liquid temperature in the boiling flask). 


\subsection{Prediction of RON and MON of gasoline fractional distillates}

As the IDTs are obtained based on the ASTM D689o standard condition and the low temperature IDS condition, the RON and MON are estimated with the correlations obtained in [34, 37] (correlations with uncertainties obtained from [35]). The RON of various gasoline fractional distillates are estimated with the DCN using Eq. (5). The IDT measurements at the IDS condition are used in determining the IDS with Eq. (3), from which OS is estimated with Eq. (6), and then MON, more details on IDS and prediction of OS from IDS are available in $[34,35]$. The estimated RON and MON of the fractional cuts of various FACE and certification gasolines are shown in Fig. 7, which are plotted against the liquid fuel temperature $\left(T_{\text {liquid }}\right)$ in the boiling flask. The nominal RON and MON of the full blend gasolines obtained from COAs are also shown.

$$
\begin{gathered}
\text { RON }_{\text {predicted }}=(-293 \pm 10)\left(\frac{D C N}{100}\right)^{2}+(-52 \pm 6)\left(\frac{D C N}{100}\right)+(114.1 \pm 1) \\
\text { OS }{ }_{\text {predicted }}=\frac{(34 \pm 2) \ln (I D S)}{[(0.84 \pm 0.2)+\ln (I D S)]}
\end{gathered}
$$

The results show that for most of the fuel fractional cuts, the RON is higher than its $\mathrm{MON}$, i.e., they have positive OS. However, some fractional cuts are observed to have negative OS. Cut 9 of FACE F gasoline has estimated OS of -3.7 , which could be attributed to the presence of branched isomers of heptane and octane (cf. detailed hydrocarbon analysis report (DHA) of FACE F gasoline in Supplementary Material) such as 2-methylhexane, 3-methylhexane, and 2,3-dimethylhexane that are shown to exhibit negative OS [6o]. It can also be observed that a greater spread in $\mathrm{ON}$ is observed for fuels containing more aromatic content. It is interesting to note that some of the cuts of FACE J gasoline have very low ONs, cut 6 has RON and MON near zero values.

The predicted RON and MON of the fractional cuts could provide guidelines on the design of future fuels depending on engine application. For example, it may not be advisable to use a gasoline such as FACE F gasoline for OoD engine application by on-board separation, as this would result in a high reactive high OS fuel and high octane, low or negative OS fuel. The operation of such a high octane, low or negative OS fuel at higher load condition would result in a fuel with lower OI where a fuel with higher OI would be required [11, 61]. 

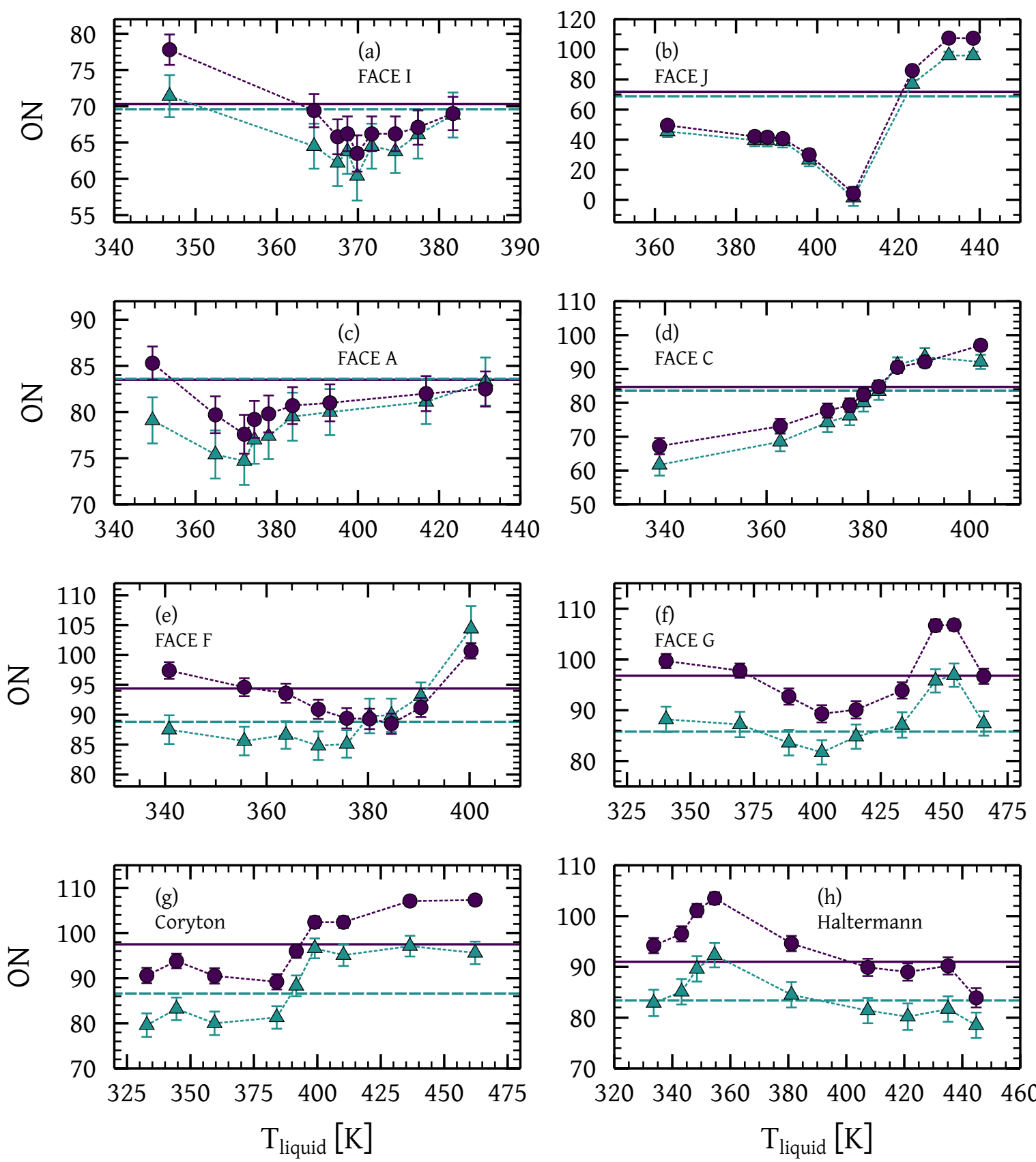

RON

- 죽-" MON

— Full blend RON _--- Full blend MON

Figure 7: Comparison of estimated $\mathrm{RON}$ and $\mathrm{MON}$ of various gasoline fractional distillates in terms of $T_{\text {liquid }}$ (liquid temperature in the boiling flask) along with full blend RON and MON from COAs. 
A spinning band distillation system was utilized in separating different fractional cuts of FACE and certification gasolines. The ignition qualities of various cuts were then analyzed with the KR-IQT at two different temperature conditions to assess the effect of chemical composition of different fractions on their IDTs. The cuts were also analyzed with high resolution ${ }^{1} \mathrm{H}$ NMR spectroscopy to identify and quantify seven different functional groups. The influence of these functional groups on the IDT of each cut was analyzed.

For fuels with low-ON low-OS (FACE I gasoline), the IDTs at both high and low temperature conditions decreases continuously with the increase in $T_{\text {liquid. }}$ This is expected because such fuels have low aromatic content and high paraffinic $\mathrm{CH}_{2}$ groups (longer chains) in the last cuts which are also observed to have high reactivity. For fuels with low-ON mid-OS (FACE J gasoline), the IDT is observed to decrease slightly up to their middle cuts, but the later cuts have large IDTs compared to initial cuts. This is due to the presence of higher aromatic content that have high-OS and low reactivity. For fuels with mid-ON low-OS (FACE A gasoline), the IDTs are observed to be comparable with negligible spread in IDTs. While a greater spread in IDTs was observed for mid-ON mid-OS (FACE C gasoline). The IDTs of high-ON mid-OS (FACE F gasoline) are observed to have considerable spread in IDTs at the high and low temperature conditions. The greatest spread in IDTs was observed for high-ON highOS (FACE G gasoline). For oxygenated certification gasolines, the effect of ethanol on the reactivity of the distillate cuts was evident. The effects of BPs on physical and chemical delay times were analyzed. A consistent PDT for different cuts of different gasoline results in chemical delay times being the major contributor to the total IDT, which are dictated by the constituents in each cut of gasoline. The RON and MON of various gasoline fractional cuts was also estimated; that could provide guidelines on the selection of components for fuel design.

\section{ACKNOWLEDGMENTS}

This study was funded by Saudi Aramco and the Clean Combustion Research Center at King Abdullah University of Science and Technology (KAUST) under the FUELCOM program. The authors also acknowledge funding from the KAUST Clean Fuels Consortium and its members. 


\section{REFERENCES}

[1] G. T. Kalghatgi, The outlook for fuels for internal combustion engines, Int. J. Engine Res. 15 (4) (2014) 383-398.

[2] G. Kalghatgi, Developments in internal combustion engines and implications for combustion science and future transport fuels, Proc. Combust. Inst. 35 (1) (2015) 101-115.

[3] M. P. Musculus, P. C. Miles, L. M. Pickett, Conceptual models for partially premixed low-temperature diesel combustion, Prog. Energy Combust. Sci. 39 (2) (2013) $246-283$.

[4] J. E. Dec, Advanced compression-ignition enginesunderstanding the in-cylinder processes, Proc. Combust. Inst. 32 (2) (2009) 2727-2742.

[5] J. B. Heywood, Internal combustion engine fundamentals, 2nd Edition, McgrawHill Education, 2018.

[6] R. Stone, Introduction to internal combustion engines, Springer, 1999.

[7] ASTM D2699-13b, Standard test method for research octane number of sparkignition engine fuel, ASTM International.

[8] ASTM D270o, Standard test method for motor octane number of spark-ignition engine fuel, ASTM International.

[9] G. T. Kalghatgi, Fuel anti-knock quality - Part I. Engine studies, SAE Technical Paper 2001-01-3584.

[10] G. T. Kalghatgi, Fuel anti-knock quality - Part II. Vehicle studies-how relevant is motor octane number (MON) in modern engines?, SAE Technical Paper 2001-013585 .

[11] G. T. Kalghatgi, Auto-ignition quality of practical fuels and implications for fuel requirements of future SI and HCCI engines, SAE Technical Paper 2005-01-0239.

[12] A. Prakash, C. Wang, A. Janssen, A. Aradi, R. Cracknell, Impact of fuel sensitivity (RON-MON) on engine efficiency, SAE International Journal of Fuels and Lubricants 10 (1) (2017) 115-125.

[13] G. Kalghatgi, R. Stone, Fuel requirements of spark ignition engines, Proceedings of the Institution of Mechanical Engineers, Part D: Journal of Automobile Engineering 232 (1) (2018) 22-35. 
[14] K. Morganti, A. Alzubail, M. Abdullah, Y. Viollet, R. Head, J. Chang, G. Kalghatgi, Improving the efficiency of conventional spark-ignition engines using octaneon-demand combustion-part ii: Vehicle studies and life cycle assessment, SAE Technical Paper 2016-01-0683.

[15] J. Chang, Y. Viollet, A. Alzubail, A. F. N. Abdul-Manan, A. Al Arfaj, Octane-ondemand as an enabler for highly efficient spark ignition engines and greenhouse gas emissions improvement, SAE Technical Paper 2015-01-1264.

[16] Y. Viollet, M. Abdullah, A. Alhajhouje, J. Chang, Characterization of high efficiency octane-on-demand fuels requirement in a modern spark ignition engine with dual injection system, SAE Technical Paper 2015-01-1265.

[17] R. Hodgkinson, Fuel system for separating volatile fuel from gasoline, US Patent 3,794,000 (1974).

[18] T. Wallington, E. Kaiser, J. Farrell, Automotive fuels and internal combustion engines: a chemical perspective, Chemical Society Reviews 35 (4) (2006) 335-347.

[19] W. Pitz, N. Cernansky, F. Dryer, F. Egolfopoulos, J. Farrell, D. Friend, H. Pitsch, Development of an experimental database and chemical kinetic models for surrogate gasoline fuels, SAE technical paper (2007-01-0175) (2007) 0175.

[20] A. G. Abdul Jameel, V. V. Oudenhoven, A.-H. Emwas, S. M. Sarathy, Predicting octane number using nuclear magnetic resonance spectroscopy and artificial neural networks, Energy Fuels 32 (5) (2018) 6309-6329.

[21] A. G. Abdul Jameel, N. Naser, A.-H. Emwas, S. Dooley, S. M. Sarathy, Predicting fuel ignition quality using $\mathrm{IH}$ NMR spectroscopy and multiple linear regression, Energy Fuels 30 (11) (2016) 9819-9835.

[22] E. J. Barrientos, M. Lapuerta, A. L. Boehman, Group additivity in soot formation for the example of c-5 oxygenated hydrocarbon fuels, Combust. Flame 160 (8) (2013) 1484-1498.

[23] S. M. Sarathy, T. Javed, F. Karsenty, A. Heufer, W. Wang, S. Park, A. Elwardany, A. Farooq, C. K. Westbrook, W. J. Pitz, M. A. Oehlschlaeger, G. Dayma, H. J. Curran, P. Dagaut, A comprehensive combustion chemistry study of $2,5^{-}$ dimethylhexane, Combust. Flame 161 (6) (2014) 1444-1459.

[24] A. G. Abdul Jameel, N. Naser, G. Issayev, J. Touitou, M. K. Ghosh, A.-H. Emwas, A. Farooq, S. Dooley, S. M. Sarathy, A minimalist functional group (MFG) approach for surrogate fuel formulation, Combust. Flame 192 (2018) 250-271.

[25] A. G. Abdul Jameel, S. M. Sarathy, Lube products: Molecular characterization of base oils, Encyclopedia of Analytical Chemistry: Applications, Theory and Instrumentation (2018) 1-14. 
[26] A. M. Elbaz, A. Gani, N. Hourani, A.-H. Emwas, S. M. Sarathy, W. Roberts, TG/DTG, FT-ICR mass spectrometry, and NMR spectroscopy study of heavy fuel oil, Energy Fuels 29 (12) (2015) 7825-7835.

[27] A. G. Abdul Jameel, A. M. Elbaz, A.-H. Emwas, W. L. Roberts, S. M. Sarathy, Calculation of average molecular parameters, functional groups, and a surrogate molecule for heavy fuel oils using $1 \mathrm{H}$ and $13 \mathrm{C}$ nuclear magnetic resonance spectroscopy, Energy Fuels 30 (5) (2016) 3894-3905.

[28] ASTM D689o, Standard test method for determination of ignition delay and derived cetane number DCN of diesel fuel oils by combustion in a constant volume chamber, ASTM International.

[29] W. Cannella, M. Foster, G. Gunter, W. Leppard, FACE gasolines and blends with ethanol: detailed characterization of physical and chemical properties, CRC Report No AVFL-24.

URL http://www.crcao.com/reports/recentstudies2014/AVFL-24/AVFL-24\% 20FACE $\% 20$ Gasolines $\% 20$ Report $\% 20-\% 20071414$.pdf

[30] T. Hetzel, The development of diesel fuel testing, Penn. State College Eng. Exp. Sta. Bull. No. 45, 30 (37) (1936).

[31] J. L. Burger, N. Schneider, T. J. Bruno, Application of the advanced distillation curve method to fuels for advanced combustion engine gasolines, Energy Fuels 29 (7) (2015) 4227-4235.

[32] Coordinating Research Council (CRC), Fuels for advanced combustion engines (FACE) working group mission statement.

URL https://crcao.org/publications/advancedVehiclesFuelsLubricants/ FACE/FACE\%20Revised\%20Mission\%20Statement_Jan2016.pdf

[33] ASTM D2789, Standard test method for hydrocarbon types in low olefinic gasoline by mass spectrometry, ASTM International.

[34] N. Naser, S. M. Sarathy, S. H. Chung, Ignition delay time sensitivity in ignition quality tester (IQT) and its relation to octane sensitivity, Fuel 233 (2018) 412-419.

[35] N. Naser, Autoignition behavior of practical fuels, PhD dissertation (2018). URL http://hdl.handle.net/10754/628530

[36] S. Y. Yang, N. Naser, S. H. Chung, J. Cha, Effect of temperature, pressure and equivalence ratio on ignition delay in ignition quality tester (IQT): Diesel, n-heptane, and iso-octane fuels under low temperature conditions, SAE International Journal of Fuels and Lubricants 8 (2015) 537-548. 
[37] N. Naser, S. Y. Yang, G. Kalghatgi, S. H. Chung, Relating the octane numbers of fuels to ignition delay times measured in an ignition quality tester (IQT), Fuel 187 (2017) 117-127.

[38] L. Hildingsson, G. Kalghatgi, N. Tait, B. Johansson, A. Harrison, Fuel octane effects in the partially premixed combustion regime in compression ignition engines, SAE Technical Paper 2009-01-2648.

[39] J. Chang, G. Kalghatgi, A. Amer, Y. Viollet, Enabling high efficiency direct injection engine with naphtha fuel through partially premixed charge compression ignition combustion, SAE Technical Paper 2012-01-0677.

[40] J. Chang, Y. Viollet, A. Amer, G. Kalghatgi, Fuel economy potential of partially premixed compression ignition (PPCI) combustion with naphtha fuel, SAE Technical Paper 2013-01-2701.

[41] H. Yang, S. Shuai, Z. Wang, J. Wang, H. Xu, Performance of straight-run naphtha single-and two-stage combustion modes from low to high load, Int. J. Engine Res. 14 (5) (2013) 469-478.

[42] K. Kim, Z. Wang, B. Wang, S. Shuai, H. Yang, C. Bae, Load expansion of naphtha multiple premixed compression ignition (MPCI) and comparison with partially premixed compression ignition (PPCI) and conventional diesel combustion (CDC), Fuel 136 (2014) 1-9.

[43] M. Lapuerta, J. J. Hernández, S. M. Sarathy, Effects of methyl substitution on the auto-ignition of C16 alkanes, Combust. Flame 164 (2016) 259-269.

[44] S. M. Sarathy, G. Kukkadapu, M. Mehl, W. Wang, T. Javed, S. Park, M. A. Oehlschlaeger, A. Farooq, W. J. Pitz, C.-J. Sung, Ignition of alkane-rich FACE gasoline fuels and their surrogate mixtures, Proc. Combust. Inst. 35 (1) (2015) 249-257.

[45] C. Yaws, Thermophysical properties of chemicals and hydrocarbons; William Andrew Inc, Norwich, NY (2008) 678.

[46] J. C. Guibet, Carburants et moteurs. Tome 1, Technip, Paris (1987).

[47] D. M. Vuilleumier, The effect of ethanol addition to gasoline on low-and intermediate-temperature heat release under boosted conditions in kinetically controlled engines, Ph.D. thesis, UC Berkeley (2016).

URL https://escholarship.org/uc/item/6jd8g04n

[48] S. M. Sarathy, A. Farooq, G. T. Kalghatgi, Recent progress in gasoline surrogate fuels, Prog. Energy Combust. Sci. 65 (2018) 67-108. 
[49] B. A. VanDerWege, S. Hochgreb, Effects of fuel volatility and operating conditions on fuel sprays in DISI engines:(1) Imaging investigation, SAE Transactions 109 (2000-01-0535) (2000) 403-416.

[5o] B. A. VanDerWege, S. Hochgreb, Effects of fuel volatility and operating conditions on fuel sprays in DISI engines:(2) PDPA investigation, SAE Transactions 109 (2000o1-0536) (2000) 417-426.

[51] Y. Ra, R. D. Reitz, J. McFarlane, C. S. Daw, Effects of fuel physical properties on diesel engine combustion using diesel and bio-diesel fuels, SAE International Journal of Fuels and Lubricants 1 (1) (2009) 703-718.

[52] L. Zigan, I. Schmitz, A. Flugel, T. Knorsch, M. Wensing, A. Leipertz, Effect of fuel properties on spray breakup and evaporation studied for a multihole direct injection spark ignition injector, Energy Fuels 24 (8) (2010) 4341-4350.

[53] E. Chapman, R. Davis, W. Studzinski, P. Geng, Fuel octane and volatility effects on the stochastic pre-ignition behavior of a 2.0 L gasoline turbocharged DI engine, SAE International Journal of Fuels and Lubricants 7 (2) (2014) 379-389.

[54] D. Kim, J. Martz, A. Violi, A surrogate for emulating the physical and chemical properties of conventional jet fuel, Combust. Flame 161 (6) (2014) 1489-1498.

[55] S. Kook, L. M. Pickett, Effect of fuel volatility and ignition quality on combustion and soot formation at fixed premixing conditions, SAE International Journal of Engines 2 (2) (2010) 11-23.

[56] A. Ahmed, G. Goteng, V. S. Shankar, K. Al-Qurashi, W. L. Roberts, S. M. Sarathy, A computational methodology for formulating gasoline surrogate fuels with accurate physical and chemical kinetic properties, Fuel 143 (2015) 290-300.

[57] N. Naser, M. Jaasim, N. Atef, S. H. Chung, H. G. Im, S. M. Sarathy, On the effects of fuel properties and injection timing in partially premixed compression ignition of low octane fuels, Fuel 207 (2017) 373-388.

[58] E. Rosseel, R. Sierens, The physical and the chemical part of the ignition delay in diesel engines, SAE International Journal of Fuels and Lubricants 961123.

[59] J. L. Mendelson, Ignition quality tester characterization with pure component and conventional navy fuels, Master thesis, University of Maryland, College Park (2016).

[6o] W. L. Kubic Jr, A group contribution method for estimating cetane and octane numbers, Tech. rep., Los Alamos National Lab.(LANL), Los Alamos, NM (United States) (2016). 
[61] G. T. Kalghatgi, K. Nakata, K. Mogi, Octane appetite studies in direct injection spark ignition DISI engines, SAE Technical Paper 2005-01-0244. 
SUPPLEMENTARY MATERIAL: THE INFLUENCE OF CHEMICAL COMPOSITION ON IGNITION DELAY TIMES OF GASOLINE FRACTIONS

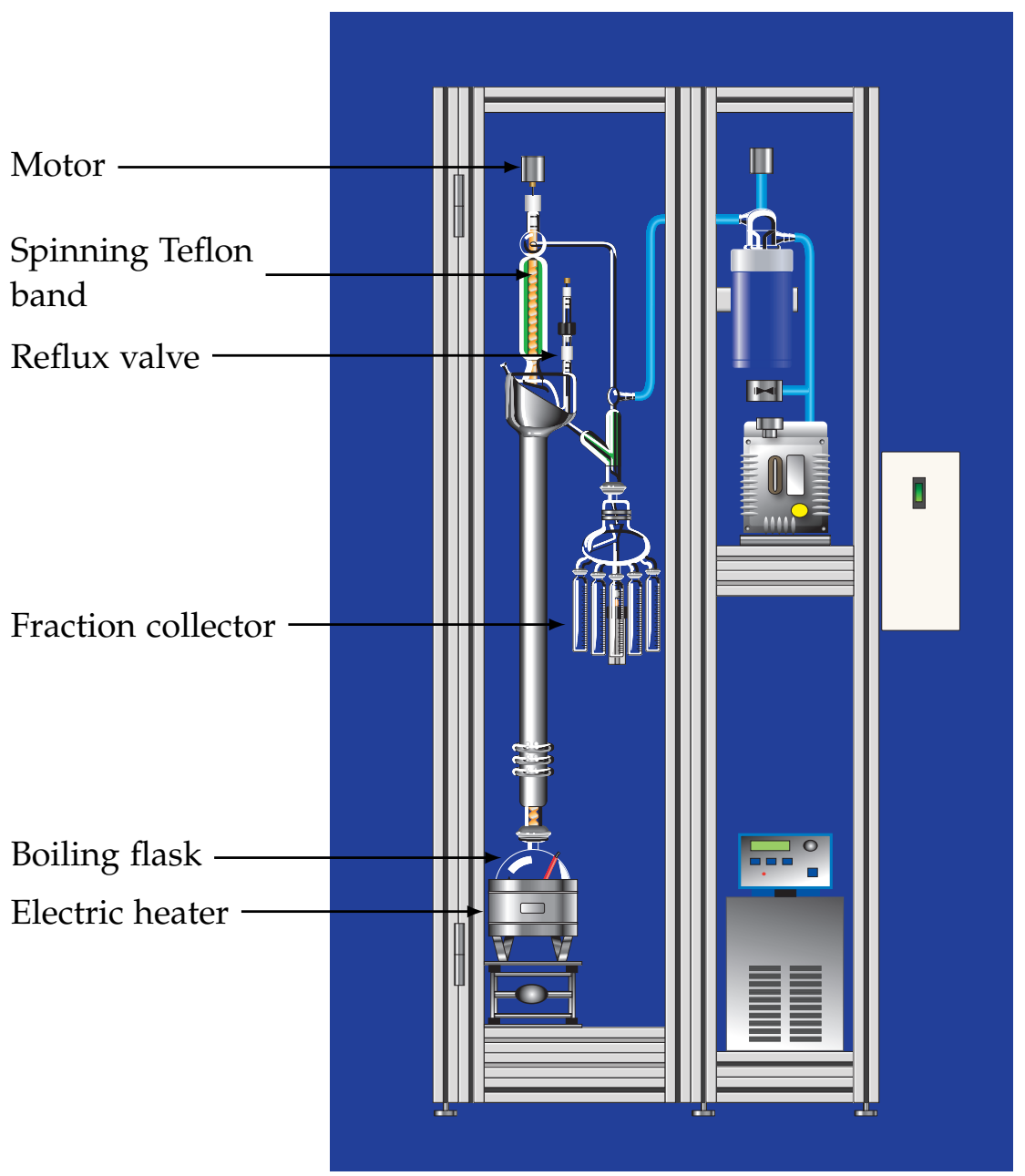

Figure S1: Schematic of spinning band distillation system. Reproduced with permission from $B / R$ instruments.

S2 NUCLEAR MAgNETIC RESONANCE (NMR) SPECTROSCOPY

The NMR spectra were acquired using NMR spectrometer (Bruker $700 \mathrm{MHz}$ AVANACIII) equipped with Bruker CPTCI multinuclear CryoProbe (Bruker BioSpin). Samples were prepared by dissolving $70 \mu \mathrm{L}$ of a sample (various gasolines and their cuts) in $600 \mu \mathrm{L}$ of deuterated chloroform $\mathrm{CDCl}_{3}$ solvent inside $5 \mathrm{~mm}$ NMR tubes. To 
achieve a high signal-to-noise ratio, the ${ }^{1} \mathrm{H}$ NMR spectra were recorded by collecting 64 scans with a recycle delay time of $10 \mathrm{~s}$. Each spectrum was recorded using one-pulse sequence through a standard (zg) program from a pulse library (Bruker). The temperature for all experiments was maintained at $298 \mathrm{~K}$. Chemical shifts were determined relative to a solvent peak for $\mathrm{CDCl}_{3}$ at $7.24 \mathrm{ppm}$ as an internal chemical shift reference. The flame ionization detector (FID) signals were amplified by applying exponential line-broadening factor of $0.3 \mathrm{~Hz}$ prior to a Fourier transformation. Software (Bruker BioSpin, Topspin 3.5 $\mathrm{pl} 7$ and MesReNova) were used to collect and analyze the data.

Table S1: ${ }^{1} \mathrm{H}$ NMR assignments.

\begin{tabular}{cc}
\hline $\begin{array}{c}\text { Chemical shift } \\
\text { [ppm] }\end{array}$ & ${ }^{1} \mathrm{H}$ type \\
\hline $6.42-8.99$ & Aromatic $\mathrm{CH}$ groups \\
$4.50-6.42$ & Olefinic $\mathrm{CH}$ and $\mathrm{CH}_{2}$ groups \\
$3.60-3.80$ & Ethanolic $\mathrm{OH}$ groups \\
$2.88-3.40$ & $\mathrm{CH}_{\text {group }} \alpha$ to aromatic ring \\
$2.64-2.88$ & $\mathrm{CH}_{2}$ group $\alpha$ to aromatic ring \\
$2.04-2.64$ & $\mathrm{CH}_{3}$ group $\alpha$ to aromatic ring \\
$1.57-1.96$ & Naphthenic $\mathrm{CH}$ and $\mathrm{CH}_{2}$ groups \\
$1.39-1.57$ & Paraffinic $\mathrm{CH}$ groups \\
$0.94-1.39$ & Paraffinic $\mathrm{CH}_{2}$ groups \\
$0.25-0.94$ & Paraffinic $\mathrm{CH}_{3}$ groups \\
\hline
\end{tabular}




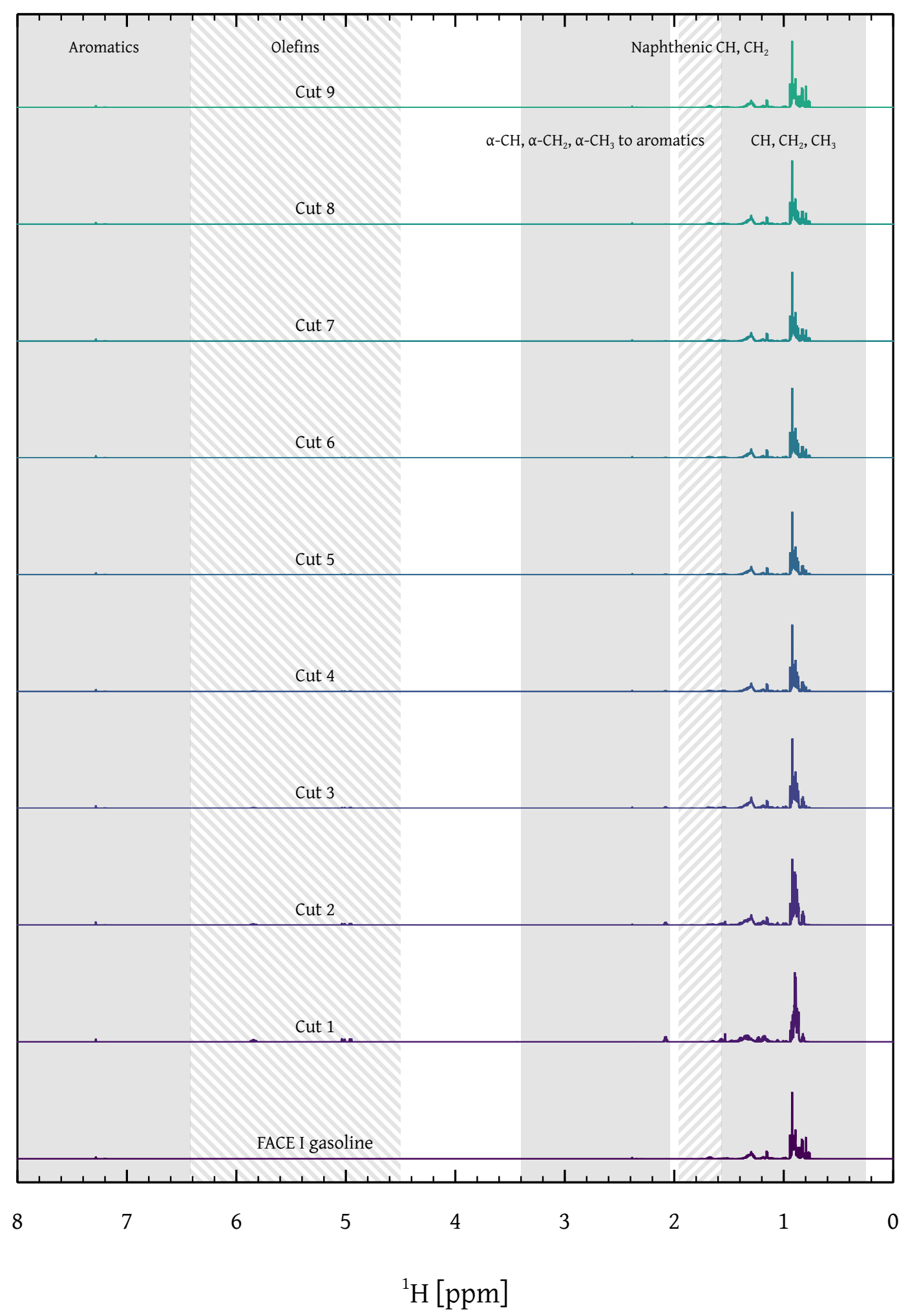

Figure S2: ${ }^{1} \mathrm{H}$ NMR spectra of FACE I gasoline and their cuts. 


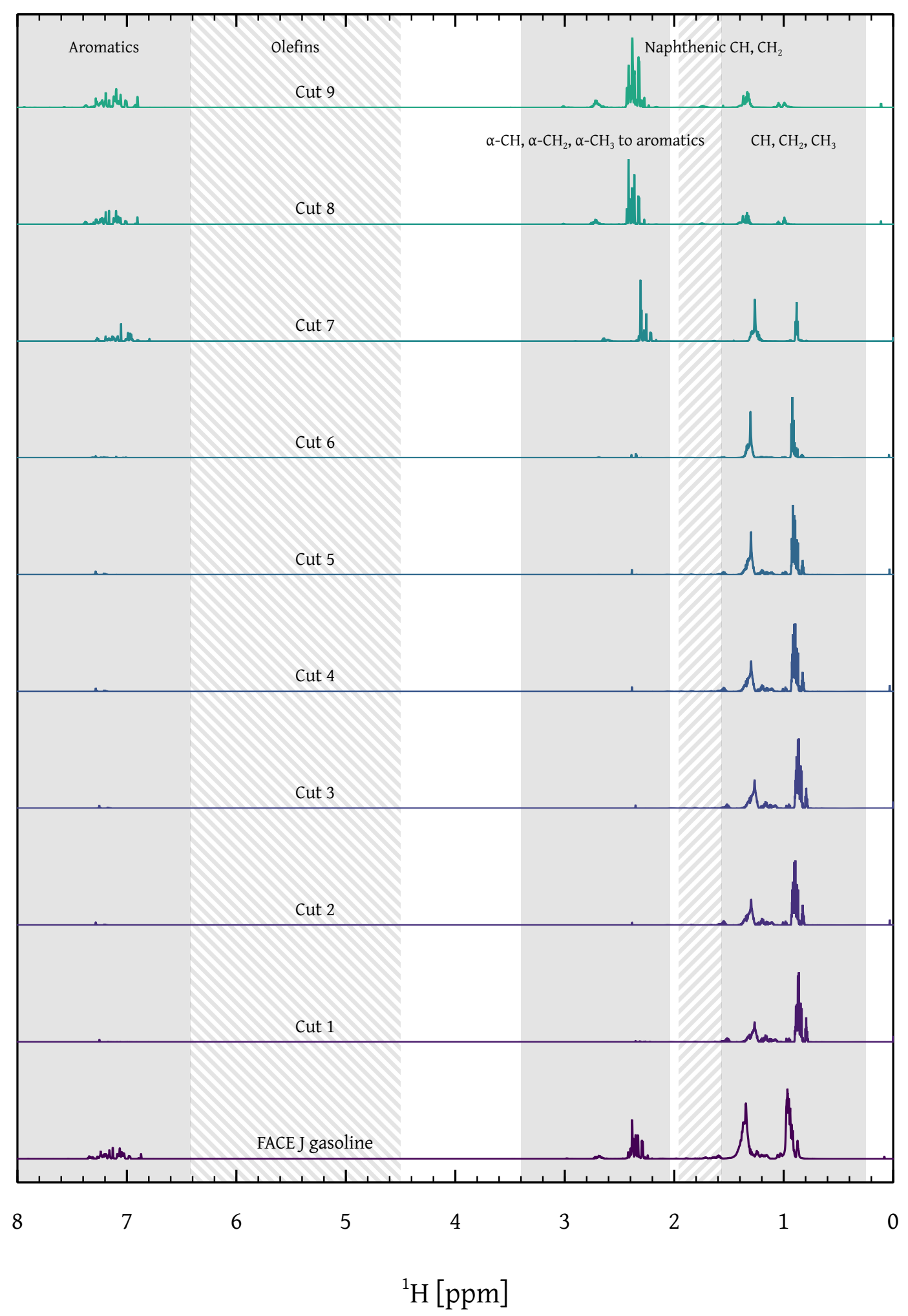

Figure $\mathrm{S}_{3}:{ }^{1} \mathrm{H}$ NMR spectra of FACE J gasoline and their cuts. 


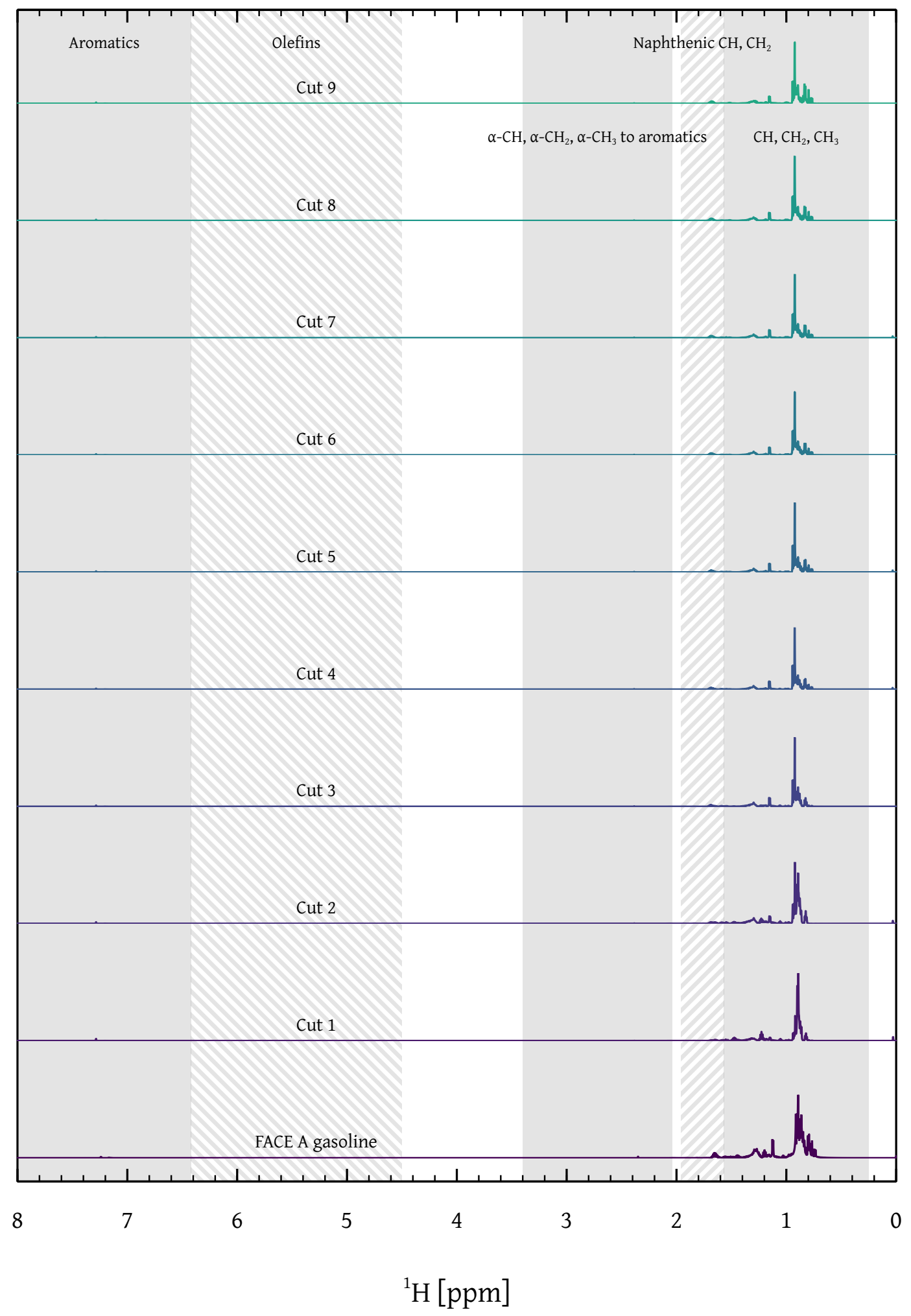

Figure $\mathrm{S}_{4}:{ }^{1} \mathrm{H}$ NMR spectra of FACE A gasoline and their cuts. 


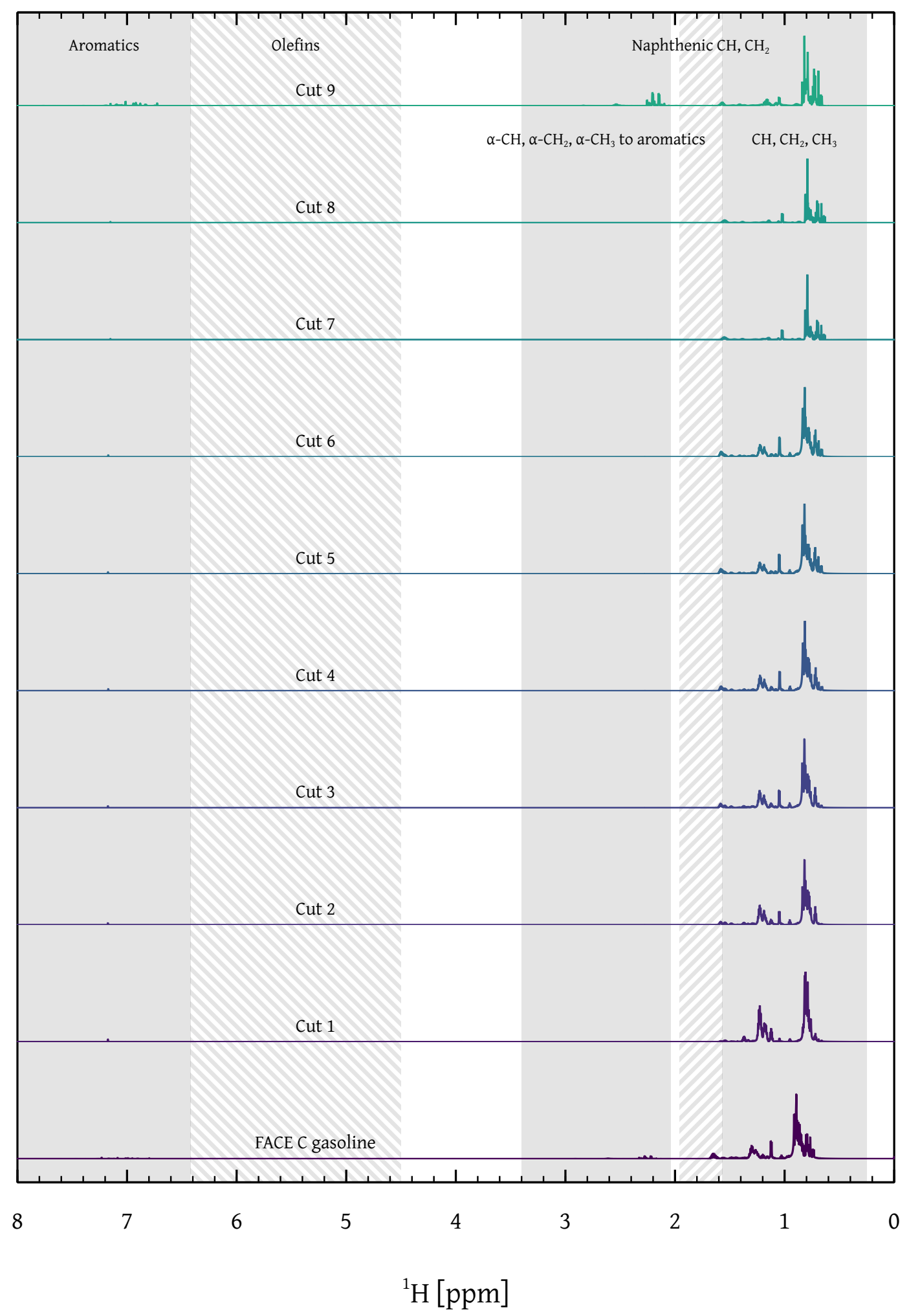

Figure $\mathrm{S}_{5}:{ }^{1} \mathrm{H}$ NMR spectra of FACE C gasoline and their cuts. 


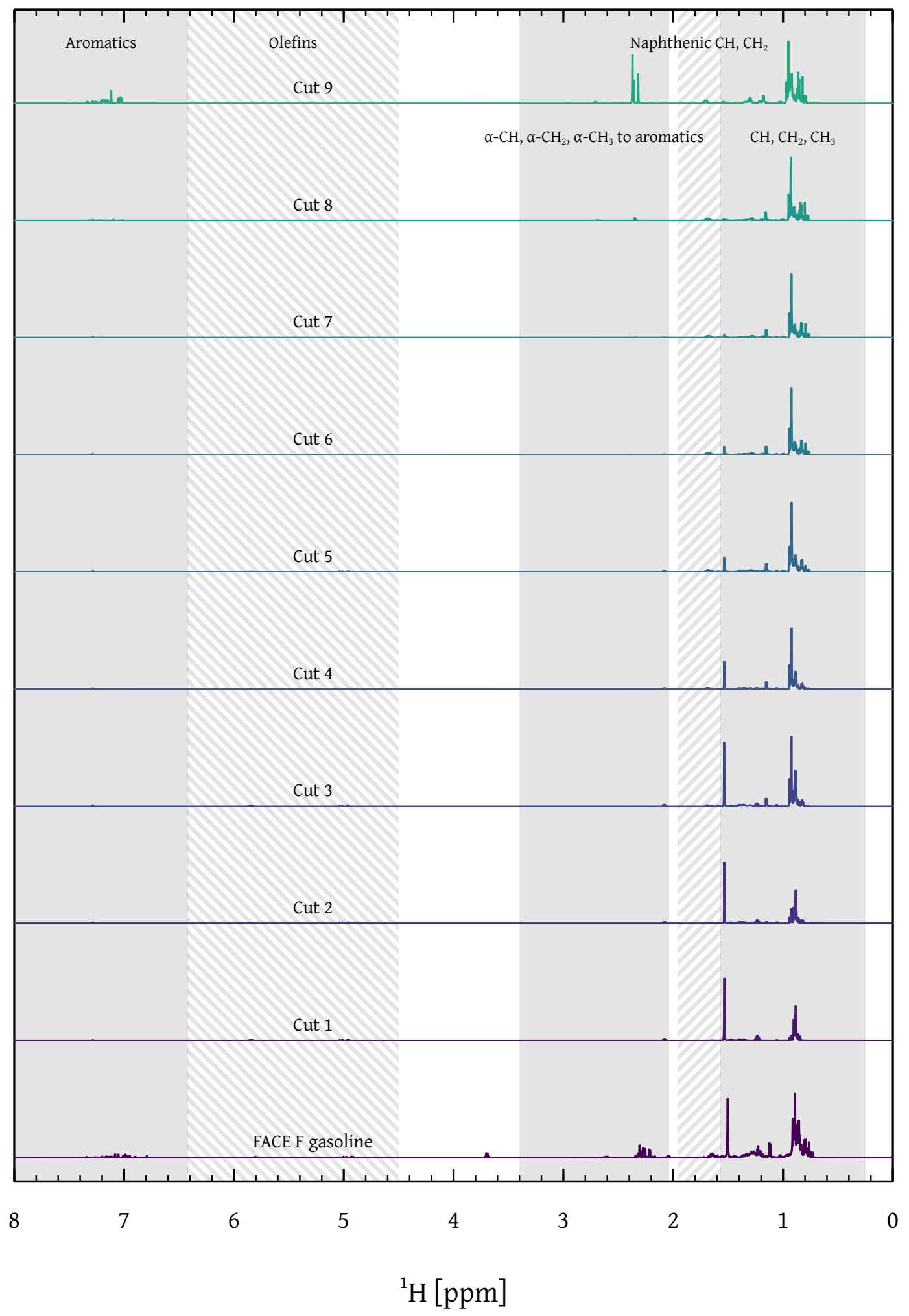

Figure S6: ${ }^{1} \mathrm{H}$ NMR spectra of FACE F gasoline and their cuts. 


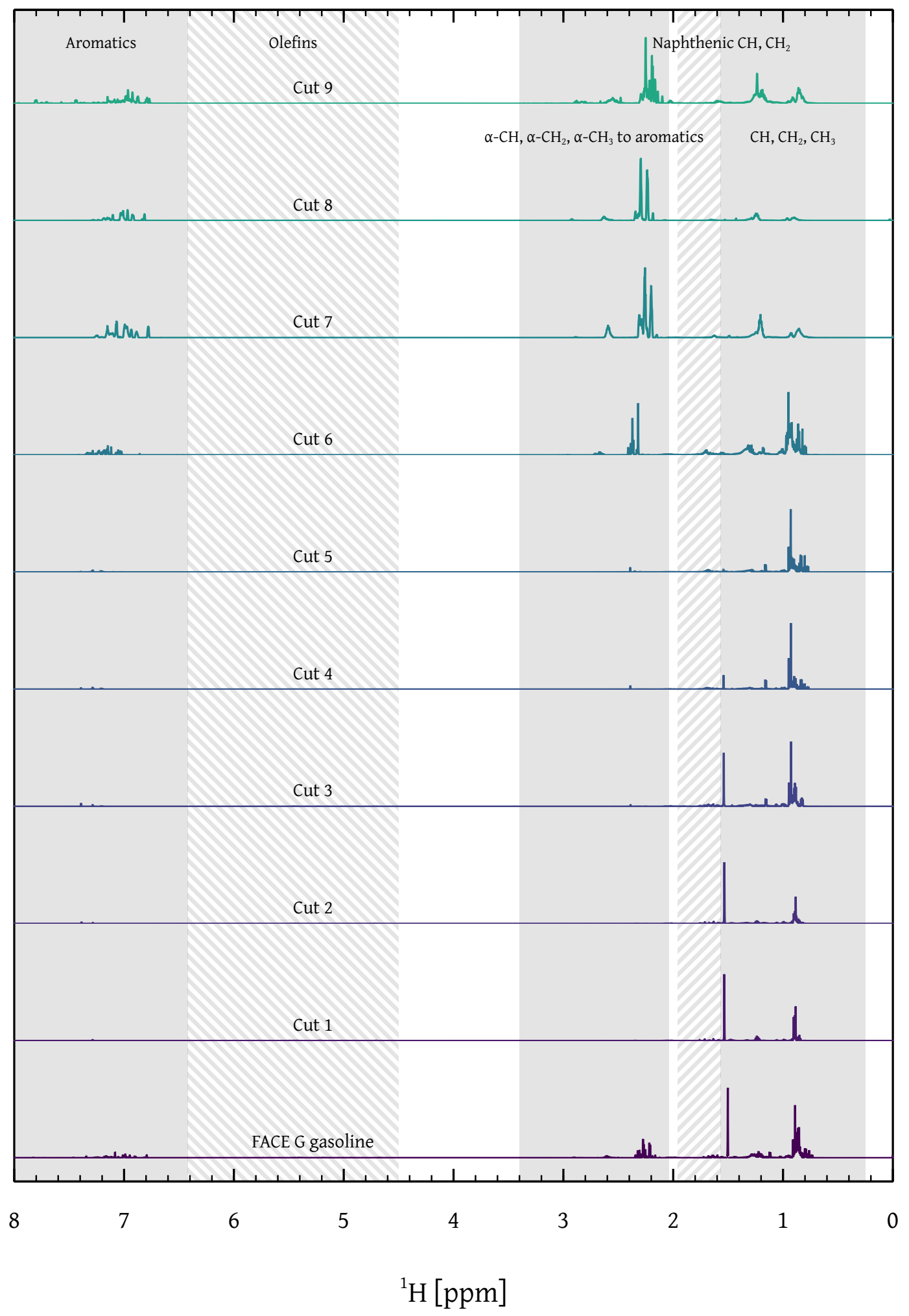

Figure S7: ${ }^{1} \mathrm{H}$ NMR spectra of FACE G gasoline and their cuts. 


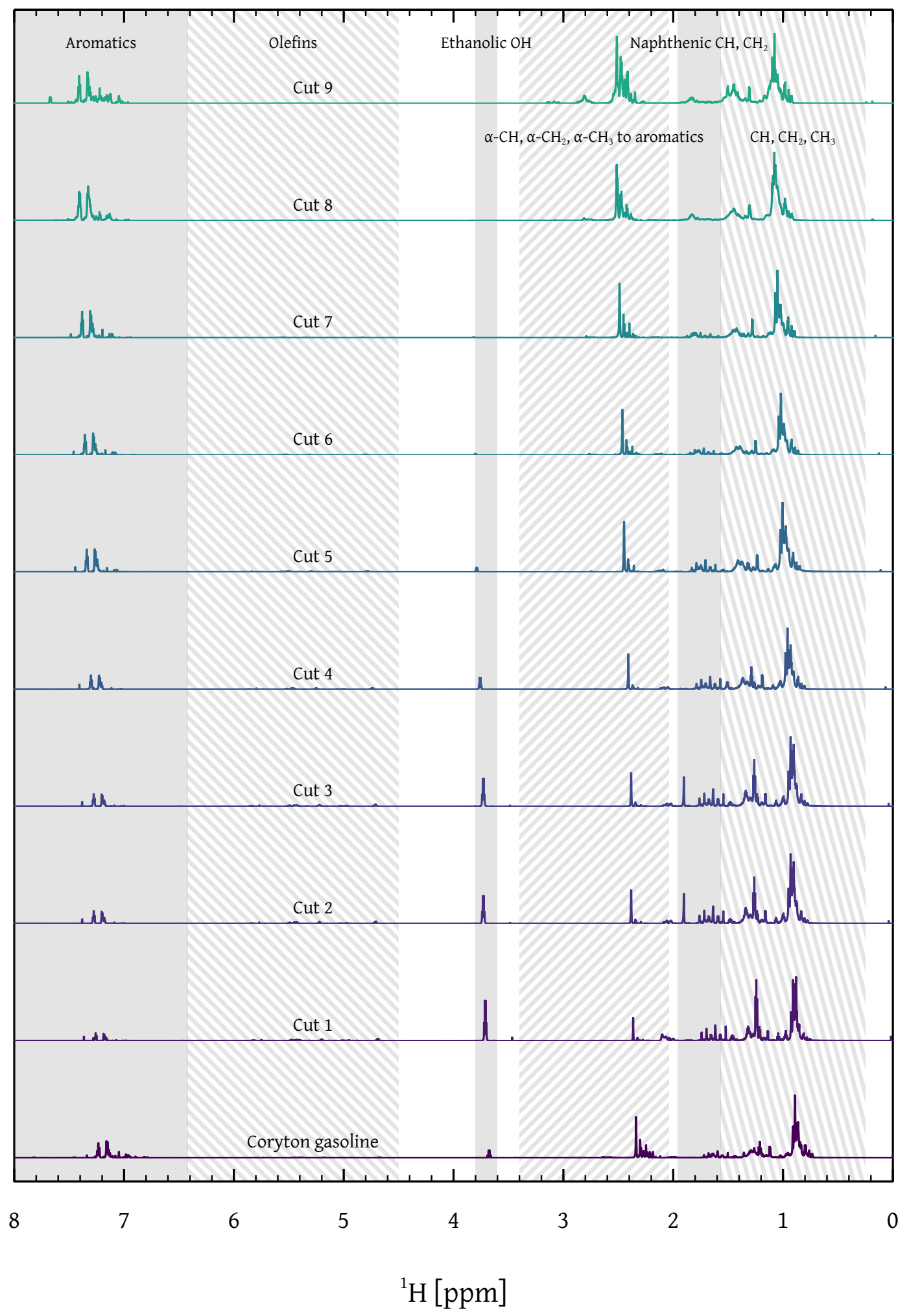

Figure S8: ${ }^{1} \mathrm{H}$ NMR spectra of Coryton gasoline and their cuts. 


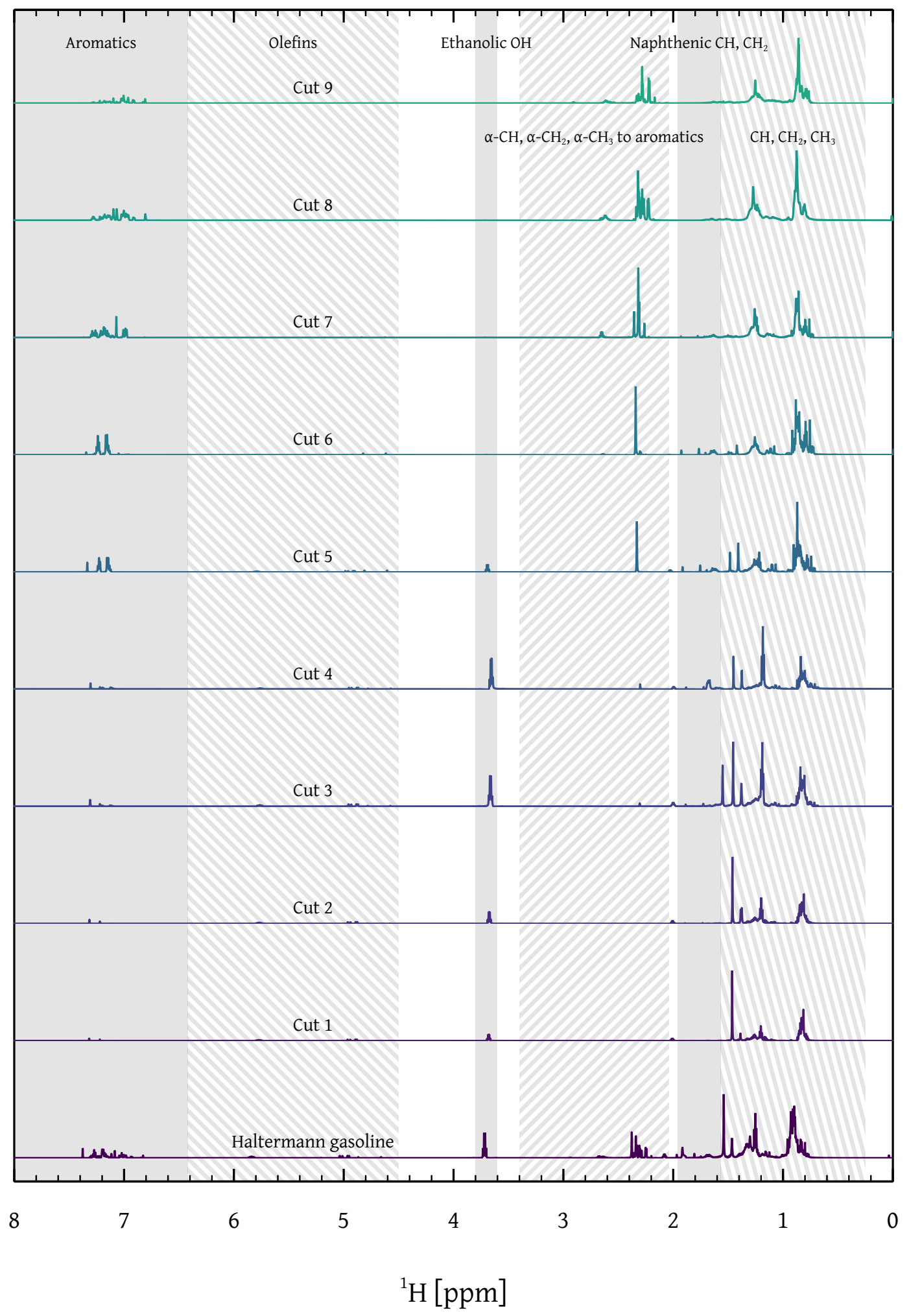

Figure S9: ${ }^{1} \mathrm{H}$ NMR spectra of Haltermann gasoline and their cuts. 

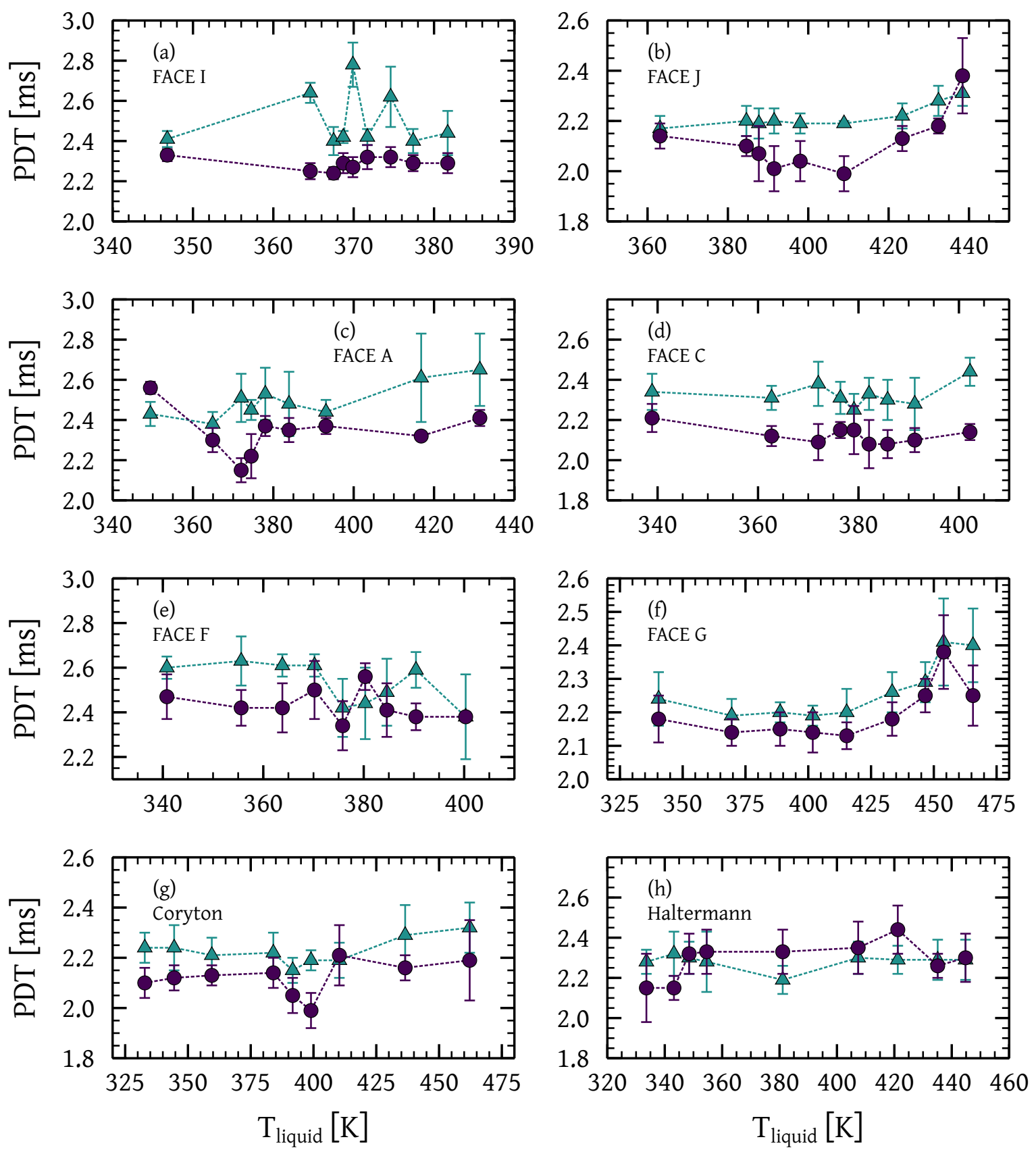

DCN condition

- ㅈ- IDS condition

Figure S10: Comparison of the relative contribution of the physical delay times of various fractional cuts in terms of $T_{\text {liquid }}$ (liquid temperature in the boiling flask) 
DETAILED HYDROCARBON ANALYSIS (DHA) REPORT OF FACE F GASOLINE

\begin{tabular}{|lr|}
\hline Hydrocarbon Expert V4.2 & Sun Jun 16 13:26:28 2013 \\
\hline $\begin{array}{l}\text { File: C:IPIONA3I13-00769_FID2_B.CDF } \\
\text { Sample: KAUST SAMPLE\# F }\end{array}$ & Page 1 \\
Parameter: C:IHPCHEMIHCE4113-00769_KAUST\#F & Operator: AMA \\
LIMS Id: & \\
\hline
\end{tabular}

\section{Summary by Group}

\begin{tabular}{|c|c|c|c|}
\hline Group & \%Wgt & \%Vol & \%Mol \\
\hline Paraffin & 3.796 & 4.228 & 4.775 \\
\hline I-Paraffins & 65.515 & 67.355 & 60.966 \\
\hline $\begin{array}{l}\text { Aromatics } \\
\text { Mono-Aromatics } \\
\text { Naphthalenes } \\
\text { Naphtheno/Olefino-Benz } \\
\text { Indenes }\end{array}$ & $\begin{array}{l}9.450 \\
9.450 \\
0.000 \\
0.000 \\
0.000\end{array}$ & $\begin{array}{l}7.661 \\
7.661 \\
0.000 \\
0.000 \\
0.000\end{array}$ & $\begin{array}{l}8.405 \\
8.405 \\
0.000 \\
0.000 \\
0.000\end{array}$ \\
\hline $\begin{array}{l}\text { Naphthenes } \\
\text { Mono-Naphthenes } \\
\text { Di/Bicyclo-Naphthenes }\end{array}$ & $\begin{array}{r}12.191 \\
12.191 \\
0.000\end{array}$ & $\begin{array}{r}11.473 \\
11.473 \\
0.000\end{array}$ & $\begin{array}{r}15.799 \\
15.799 \\
0.000\end{array}$ \\
\hline $\begin{array}{l}\text { Olefins } \\
\text { n-Olefins } \\
\text { Iso-Olefins } \\
\text { Naphtheno-Olefins } \\
\text { Di-Olefins }\end{array}$ & $\begin{array}{l}9.026 \\
0.242 \\
8.769 \\
0.000 \\
0.015\end{array}$ & $\begin{array}{l}9.264 \\
0.249 \\
9.000 \\
0.000 \\
0.015\end{array}$ & $\begin{array}{r}10.036 \\
0.181 \\
9.838 \\
0.000 \\
0.017\end{array}$ \\
\hline Oxygenates & 0.000 & 0.000 & 0.000 \\
\hline Unidentified & 0.023 & 0.018 & 0.020 \\
\hline Plus & 0.000 & 0.000 & 0.000 \\
\hline
\end{tabular}


DETAILED HYDROCARBON ANALYSIS (DHA) REPORT OF FACE F GASOLINE

\begin{tabular}{|lr|}
\hline Hydrocarbon Expert V4.2 & Sun Jun 16 13:26:28 2013 \\
\hline \begin{tabular}{ll}
\hline File: C:IPIONA3I13-00769_FID2_B.CDF \\
Sample: KAUST SAMPLE\# F
\end{tabular} & Page 1 \\
Parameter: C:IHPCHEMIHCE4I13-00769_KAUST\#F & Operator: AMA \\
LIMS Id: &
\end{tabular}

\section{Components by Group}

\begin{tabular}{|c|c|c|c|c|c|}
\hline$\frac{\text { Group }}{\text { Paraffin }}$ & $\begin{array}{r}\text { Time } \\
8.171 \\
10.205 \\
15.138 \\
25.109 \\
81.288\end{array}$ & $\begin{array}{l}\text { Component } \\
\text { n-Butane } \\
\text { n-Pentane } \\
\text { n-Hexane } \\
\text { n-Heptane } \\
\text { n-Decane }\end{array}$ & $\begin{array}{l}\% \text { Wgt } \\
1.713 \\
0.041 \\
0.012 \\
2.018 \\
0.011\end{array}$ & $\begin{array}{l}\frac{\% \text { Vol }}{2.082} \\
0.046 \\
0.013 \\
2.076 \\
0.011\end{array}$ & $\begin{array}{l}\frac{\% \text { Mol }}{2.792} \\
0.054 \\
0.014 \\
1.907 \\
0.007\end{array}$ \\
\hline I-Paraffins & $\begin{array}{r}7.811 \\
8.353 \\
9.489 \\
11.552 \\
13.067 \\
13.290 \\
14.096 \\
16.899 \\
17.387 \\
17.858 \\
19.674 \\
20.981 \\
21.181 \\
21.964 \\
23.217 \\
23.682 \\
30.186 \\
30.339 \\
30.502 \\
33.143 \\
33.835 \\
35.052 \\
35.266 \\
36.151 \\
36.411 \\
36.577 \\
36.679 \\
37.484 \\
45.491 \\
48.559 \\
50.040 \\
55.161 \\
61.140 \\
61.343 \\
65.358 \\
68.792 \\
70.437 \\
71.129 \\
77.880 \\
79.050 \\
84.346\end{array}$ & $\begin{array}{l}\text { i-Butane } \\
\text { 2,2-Dimethylpropane } \\
\text { i-Pentane } \\
\text { 2,2-Dimethylbutane } \\
\text { 2,3-Dimethylbutane } \\
\text { 2-Methylpentane } \\
\text { 3-Methylpentane } \\
\text { 2,2-Dimethylpentane } \\
\text { 2,4-Dimethylpentane } \\
\text { 2,2,3-Trimethylbutane } \\
\text { 3,3-Dimethylpentane } \\
\text { 2-Methylhexane } \\
\text { 2,3-Dimethylpentane } \\
\text { 3-Methylhexane } \\
\text { 3-Ethylpentane } \\
\text { 2,2,4-Trimethylpentane } \\
\text { 2,5-Dimethylhexane } \\
\text { 2,2,3-Trimethylpentane } \\
\text { 2,4-Dimethylhexane } \\
\text { 2,3,4-Trimethylpentane } \\
\text { 2,3,3-Trimethylpentane } \\
\text { 2,3-Dimethylhexane } \\
\text { 2-Methyl-3-ethylpentane } \\
\text { 2-Methylheptane } \\
\text { 4-Methylheptane } \\
\text { 3-Methyl-3-ethylpentane } \\
\text { 3,4-Dimethylhexane } \\
\text { 3-Methylheptane } \\
\text { 2,3,4-Trimethylhexane } \\
\text { 2,2,3-Trimethylhexane } \\
\text { 2,5-Dimethylheptane } \\
\text { 2,3-Dimethylheptane } \\
\text { C10 - IsoParaffin - } 1 \\
\text { C10 - Isoparaffin - 2 } \\
\text { 3,3,5-TrimethylHeptane } \\
\text { 2,3,6-trimethylheptane } \\
\text { 2,5-Dimethyloctane } \\
\text { C10 - IsoParaffin - 3 } \\
\text { Heptane, 2,2,3,5-tetramethyl- } \\
\text { C10 - IsoParaffin - 7 } \\
\text { C11 Isoparaffin - 4 } \\
\text { (1) }\end{array}$ & $\begin{array}{l}0.037 \\
0.007 \\
7.369 \\
4.218 \\
1.205 \\
0.414 \\
0.188 \\
0.008 \\
3.460 \\
0.036 \\
0.137 \\
1.795 \\
5.280 \\
2.275 \\
0.213 \\
20.950 \\
1.646 \\
0.564 \\
2.141 \\
5.760 \\
4.934 \\
1.566 \\
0.061 \\
0.063 \\
0.021 \\
0.135 \\
0.160 \\
0.059 \\
0.128 \\
0.024 \\
0.068 \\
0.035 \\
0.030 \\
0.184 \\
0.131 \\
0.070 \\
0.019 \\
0.037 \\
0.032 \\
0.018 \\
0.023\end{array}$ & $\begin{array}{r}0.047 \\
0.008 \\
8.366 \\
4.571 \\
1.281 \\
0.446 \\
0.199 \\
0.008 \\
3.618 \\
0.037 \\
0.139 \\
1.860 \\
5.343 \\
2.329 \\
0.215 \\
21.300 \\
1.670 \\
0.554 \\
2.150 \\
5.636 \\
4.779 \\
1.547 \\
0.061 \\
0.064 \\
0.021 \\
0.134 \\
0.157 \\
0.059 \\
0.122 \\
0.024 \\
0.066 \\
0.034 \\
0.029 \\
0.177 \\
0.127 \\
0.049 \\
0.018 \\
0.036 \\
0.023 \\
0.018 \\
0.021\end{array}$ & $\begin{array}{r}0.060 \\
0.009 \\
9.674 \\
4.636 \\
1.325 \\
0.455 \\
0.207 \\
0.008 \\
3.271 \\
0.034 \\
0.130 \\
1.696 \\
4.991 \\
2.151 \\
0.202 \\
17.373 \\
1.365 \\
0.467 \\
1.775 \\
4.777 \\
4.091 \\
1.299 \\
0.051 \\
0.052 \\
0.017 \\
0.112 \\
0.133 \\
0.049 \\
0.095 \\
0.018 \\
0.050 \\
0.026 \\
0.020 \\
0.122 \\
0.087 \\
0.047 \\
0.013 \\
0.025 \\
0.020 \\
0.012 \\
0.014\end{array}$ \\
\hline
\end{tabular}


DETAILED HYDROCARBON ANALYSIS (DHA) REPORT OF FACE F GASOLINE

\begin{tabular}{|c|c|}
\hline Sun Jun 16 13:26:28 2013 & Page 2 \\
\hline $\begin{array}{l}\text { File: C:IPIONA3I13-00769_FID2_B.CDF } \\
\text { Sample: KAUST SAMPLE\#F } \\
\text { Parameter: C:IHPCHEMIHCE4I13-00769_KAUST\#F } \\
\text { LIMS Id: }\end{array}$ & $\begin{array}{r}\text { 3/24/2013 1:21:54 PM } \\
\text { Operator: AMA }\end{array}$ \\
\hline
\end{tabular}

\section{Components by Group}

\begin{tabular}{|c|c|c|c|c|c|}
\hline$\frac{\text { Group }}{\text { I-Paraffins }}$ & $\frac{\text { Time }}{85.515}$ & $\frac{\text { Component }}{\text { C11 IsoParaffin - } 6}$ & $\frac{\% W g t}{0.012}$ & $\frac{\% \text { Vol }}{0.012}$ & $\frac{\% \mathrm{Mol}}{0.007}$ \\
\hline $\begin{array}{l}\text { Aromatics } \\
\text { Mono-Aromatics }\end{array}$ & $\begin{array}{l}52.348 \\
54.603 \\
54.874 \\
60.355 \\
67.406 \\
76.161 \\
78.383\end{array}$ & $\begin{array}{l}\text { Ethylbenzene } \\
\text { m-Xylene } \\
\text { p-Xylene } \\
\text { o-Xylene } \\
\text { i-Propylbenzene } \\
\text { 1-Methyl-2-ethylbenzene } \\
\text { 1,2,4-Trimethylbenzene }\end{array}$ & $\begin{array}{l}1.352 \\
4.123 \\
1.730 \\
1.988 \\
0.017 \\
0.210 \\
0.030\end{array}$ & $\begin{array}{l}1.097 \\
3.356 \\
1.414 \\
1.589 \\
0.014 \\
0.168 \\
0.024\end{array}$ & $\begin{array}{l}1.206 \\
3.679 \\
1.544 \\
1.774 \\
0.013 \\
0.166 \\
0.023\end{array}$ \\
\hline $\begin{array}{l}\text { Naphthalenes } \\
\text { Naphtheno/Olefir } \\
\text { Indenes } \\
\text { Naphthenes }\end{array}$ & & & & & \\
\hline Mono-Naphthen€ & $\begin{array}{l}12.990 \\
21.501 \\
22.738 \\
23.082 \\
23.427 \\
27.958 \\
28.088 \\
29.965 \\
39.445 \\
40.631 \\
43.602 \\
47.111 \\
80.139\end{array}$ & $\begin{array}{l}\text { Cyclopentane } \\
\text { 1,1-Dimethylcyclopentane } \\
\text { 1t,3-Dimethylcyclopentane } \\
\text { 1c,3-Dimethylcyclopentane } \\
\text { 1t,2-Dimethylcyclopentane } \\
\text { 1c,2-Dimethylcyclopentane } \\
\text { Methylcyclohexane } \\
\text { Ethylcyclopentane } \\
\text { 3c-Ethylmethylcyclopentane } \\
\text { 1,1-Methylethylcyclopentane } \\
\text { C8 - MonoNaph - 3 } \\
\text { Cycloheptane, methyl- } \\
\text { 1t-Methyl-2-n-propylcyclohexan }\end{array}$ & $\begin{array}{r}10.777 \\
0.042 \\
0.087 \\
0.092 \\
0.112 \\
0.027 \\
0.059 \\
0.017 \\
0.871 \\
0.015 \\
0.038 \\
0.036 \\
0.018\end{array}$ & $\begin{array}{r}10.171 \\
0.039 \\
0.082 \\
0.087 \\
0.105 \\
0.026 \\
0.054 \\
0.016 \\
0.799 \\
0.014 \\
0.034 \\
0.032 \\
0.016\end{array}$ & $\begin{array}{r}14.556 \\
0.041 \\
0.084 \\
0.088 \\
0.108 \\
0.026 \\
0.057 \\
0.017 \\
0.735 \\
0.013 \\
0.032 \\
0.031 \\
0.012\end{array}$ \\
\hline \multicolumn{6}{|l|}{$\begin{array}{l}\text { Di/Bicyclo-Napht } \\
\text { Olefins }\end{array}$} \\
\hline n-Olefins & 62.809 & Nonene-1 & 0.242 & 0.249 & 0.181 \\
\hline Iso-Olefins & $\begin{array}{l}14.430 \\
15.071 \\
16.566 \\
25.399 \\
69.077 \\
77.880 \\
78.947\end{array}$ & $\begin{array}{l}\text { 2-Methylpentene-1 } \\
\text { 2-Ethylbutene-1 } \\
\text { 3-methyl-c-pentene-2 } \\
\text { 2-Methyl-2-hexene } \\
\text { 2-Methyl-3-ethyl-2-heptene } \\
\text { 3-Ethyl-2-methylheptene-2 } \\
\text { C10-iso-olefin-9 }\end{array}$ & $\begin{array}{l}8.655 \\
0.019 \\
0.012 \\
0.017 \\
0.018 \\
0.032 \\
0.016\end{array}$ & $\begin{array}{l}8.891 \\
0.019 \\
0.012 \\
0.016 \\
0.018 \\
0.032 \\
0.011\end{array}$ & $\begin{array}{l}9.742 \\
0.022 \\
0.014 \\
0.016 \\
0.012 \\
0.021 \\
0.010\end{array}$ \\
\hline $\begin{array}{l}\text { Naphtheno-Olefil } \\
\text { Di-Olefins }\end{array}$ & 15.845 & 2-methyl-1,4-pentadiene & 0.015 & 0.015 & 0.017 \\
\hline $\begin{array}{l}\text { Oxygenates } \\
\text { Unidentified }\end{array}$ & 60.078 & Unidentified & 0.023 & 0.018 & 0.020 \\
\hline Plus & & & & & \\
\hline
\end{tabular}


DETAILED hydROCARbON ANALYSis (DHA) REPORT OF FACE G GASOLINE

\begin{tabular}{|lr|}
\hline Hydrocarbon Expert V4.2 & Thu Apr 02 11:21:35 2015 \\
\hline $\begin{array}{l}\text { File: C:IPIONA3IFT-0136A_FID2_B.CDF } \\
\text { Sample: FT-00136A }\end{array}$ \\
$\begin{array}{l}\text { Parameter: C:IHPCHEMIHCE4IG95-OLEFIN_2015FID2_B } \\
\text { LIMS Id: }\end{array}$ & Page 1/22/2015 3:23:31 PM \\
\hline
\end{tabular}

\section{Summary by Group}

\begin{tabular}{lrrr} 
Group & \%Wgt & \%Vol & \%Mol \\
\cline { 2 - 3 } Paraffin & 5.749 & 6.891 & 7.779 \\
& 39.636 & 43.504 & 38.167 \\
I-Paraffins & 37.541 & 32.017 & 31.694 \\
Aromatics & 36.408 & 31.136 & 30.933 \\
$\quad$ Mono-Aromatics & 0.000 & 0.000 & 0.000 \\
$\quad$ Naphthalenes & 0.000 & 0.000 & 0.000 \\
$\quad$ Naphtheno/Olefino-Benz & 1.133 & 0.881 & 0.761 \\
$\quad$ Indenes & & & \\
& 10.780 & 10.696 & 14.006 \\
Naphthenes & 10.780 & 10.696 & 14.006 \\
$\quad$ Mono-Naphthenes & 0.000 & 0.000 & 0.000 \\
$\quad$ Di/Bicyclo-Naphthenes & & & \\
& 6.036 & 6.646 & 7.799 \\
Olefins & 2.293 & 2.596 & 3.008 \\
$\quad$ I-Olefins & 3.165 & 3.490 & 4.058 \\
$\quad$ Iso-Olefins & 0.578 & 0.560 & 0.732 \\
$\quad$ Naphtheno-Olefins & 0.000 & 0.000 & 0.000 \\
Di-Olefins & & & \\
Oxygenates & 0.259 & 0.246 & 0.556 \\
& & & \\
Unidentified & 0.000 & 0.000 & 0.000 \\
Plus & 0.000 & 0.000 & 0.000
\end{tabular}


DETAILED hydROCARbON ANALYSis (DHA) REPORT OF FACE G GASOLINE

\begin{tabular}{|lr|}
\hline Hydrocarbon Expert V4.2 & Thu Apr 02 11:21:35 2015 \\
\hline $\begin{array}{l}\text { File: C:IPIONA3IFT-0136A_FID2_B.CDF } \\
\text { Sample: FT-00136A }\end{array}$ & Page 1 \\
Parameter: C:IHPCHEMIHCE4IG95-OLEFIN_2015FID2_B & Operator: imran \\
LIMS Id: & \\
\hline
\end{tabular}

\section{Summary by Carbon}

\begin{tabular}{lrrr} 
C\# & \%Wgt & \%Vol & \%Mol \\
\hline C2 & 0.259 & 0.246 & 0.556 \\
C4 & 2.853 & 3.699 & 4.858 \\
C5 & 16.589 & 18.310 & 23.183 \\
C6 & 9.934 & 10.914 & 11.574 \\
C7 & 14.278 & 14.492 & 14.554 \\
C8 & 19.446 & 19.679 & 17.178 \\
C9 & 21.238 & 18.339 & 17.452 \\
C10 & 10.635 & 10.371 & 7.549 \\
C11 & 3.298 & 2.784 & 2.202 \\
C12 & 1.471 & 1.167 & 0.895
\end{tabular}


DETAILED hydROCARbON ANALYSis (DHA) REPORT OF FACE G GASOLINE

\begin{tabular}{|lr|}
\hline Hydrocarbon Expert V4.2 & Thu Apr 02 11:21:35 2015 \\
\hline $\begin{array}{l}\text { File: C:IPIONA3IFT-0136A_FID2_B.CDF } \\
\text { Sample: FT-00136A }\end{array}$ & Page 1 \\
Parameter: C:IHPCHEMIHCE4IG95-OLEFIN_2015FID2_B & Operator: imran \\
LIMS Id: & \\
\hline
\end{tabular}

\section{Composite by Carbon}

\begin{tabular}{|c|c|c|c|c|}
\hline$\frac{\text { Group }}{\text { Paraffin }}$ & $\begin{array}{r}\text { C\# } \\
\text { C4 } \\
\text { C5 } \\
\text { C6 } \\
\text { C7 } \\
\text { C8 } \\
\text { C9 } \\
\text { C12 }\end{array}$ & $\begin{array}{c}\text { \%Wgt } \\
2.793 \\
0.573 \\
0.398 \\
1.100 \\
0.473 \\
0.230 \\
0.182\end{array}$ & $\begin{array}{l}\text { \%Vol } \\
3.618 \\
0.686 \\
0.453 \\
1.207 \\
0.505 \\
0.241 \\
0.181\end{array}$ & $\begin{array}{l}\text { \%Mol } \\
4.756 \\
0.786 \\
0.457 \\
1.087 \\
0.410 \\
0.178 \\
0.106\end{array}$ \\
\hline I-Paraffins & $\begin{array}{l}\text { C4 } \\
\text { C5 } \\
\text { C6 } \\
\text { C7 } \\
\text { C8 } \\
\text { C9 } \\
\text { C10 } \\
\text { C11 }\end{array}$ & $\begin{array}{r}0.060 \\
5.338 \\
5.546 \\
7.119 \\
13.525 \\
0.464 \\
7.413 \\
0.171\end{array}$ & $\begin{array}{r}0.081 \\
6.461 \\
6.369 \\
7.783 \\
14.502 \\
0.492 \\
7.643 \\
0.173\end{array}$ & $\begin{array}{r}0.102 \\
7.323 \\
6.369 \\
7.032 \\
11.718 \\
0.358 \\
5.156 \\
0.108\end{array}$ \\
\hline Mono-Aromatics & $\begin{array}{r}\text { C6 } \\
\text { C7 } \\
\text { C8 } \\
\text { C9 } \\
\text { C10 } \\
\text { C11 } \\
\text { C12 }\end{array}$ & $\begin{array}{r}0.473 \\
4.163 \\
4.851 \\
20.543 \\
2.946 \\
2.451 \\
0.981\end{array}$ & $\begin{array}{r}0.404 \\
3.601 \\
4.178 \\
17.606 \\
2.516 \\
2.086 \\
0.746\end{array}$ & $\begin{array}{r}0.600 \\
4.471 \\
4.522 \\
16.916 \\
2.189 \\
1.636 \\
0.599\end{array}$ \\
\hline Indenes & $\begin{array}{l}\text { C10 } \\
\text { C11 } \\
\text { C12 }\end{array}$ & $\begin{array}{l}0.149 \\
0.676 \\
0.307\end{array}$ & $\begin{array}{l}0.116 \\
0.526 \\
0.239\end{array}$ & $\begin{array}{l}0.114 \\
0.457 \\
0.190\end{array}$ \\
\hline Mono-Naphthenes & $\begin{array}{l}\text { C5 } \\
\text { C6 } \\
\text { C7 } \\
\text { C8 }\end{array}$ & $\begin{array}{l}7.524 \\
1.081 \\
1.576 \\
0.598\end{array}$ & $\begin{array}{l}7.570 \\
1.072 \\
1.560 \\
0.494\end{array}$ & $\begin{array}{r}10.618 \\
1.272 \\
1.588 \\
0.528\end{array}$ \\
\hline n-Olefins & $\begin{array}{l}\text { C5 } \\
\text { C6 }\end{array}$ & $\begin{array}{l}1.325 \\
0.968\end{array}$ & $\begin{array}{l}1.532 \\
1.064\end{array}$ & $\begin{array}{l}1.870 \\
1.138\end{array}$ \\
\hline Iso-Olefins & $\begin{array}{r}\text { C5 } \\
\text { C6 } \\
\mathrm{C} 7 \\
\mathrm{C} 10\end{array}$ & $\begin{array}{l}1.684 \\
1.035 \\
0.320 \\
0.127\end{array}$ & $\begin{array}{l}1.921 \\
1.132 \\
0.342 \\
0.095\end{array}$ & $\begin{array}{l}2.376 \\
1.217 \\
0.376 \\
0.090\end{array}$ \\
\hline Naphtheno-Olefins & C5 & 0.145 & 0.141 & 0.211 \\
\hline
\end{tabular}


DETAILED HYDROCARBON ANALYSIS (DHA) REPORT OF FACE G GASOLINE

\begin{tabular}{|lr|}
\hline Hydrocarbon Expert V4.2 & Thu Apr 02 11:21:35 2015 \\
\hline $\begin{array}{l}\text { File: C:IPIONA3IFT-0136A_FID2_B.CDF } \\
\text { Sample: FT-00136A }\end{array}$ \\
$\begin{array}{l}\text { Parameter: C:IHPCHEMIHCE4IG95-OLEFIN_2015FID2_B } \\
\text { LIMS Id: }\end{array}$ & Page 2 \\
\hline
\end{tabular}

\section{Composite by Carbon}

\begin{tabular}{|c|c|c|c|}
\hline$\frac{\text { Group }}{\text { Naphtheno-Olefins }}$ & $\frac{\mathrm{C \#}}{\mathrm{C} 6}$ & $\frac{\% \text { Wgt }}{0.433}$ & $\frac{\% \mathrm{Vol}}{0.420}$ \\
\hline Oxygenates & C2 & 0.259 & 0.246 \\
\hline
\end{tabular}

Recovery $=100.00$ 
DETAILED hydROCARbON ANALYSis (DHA) REPORT OF FACE G GASOLINE

\begin{tabular}{|lr|}
\hline Hydrocarbon Expert V4.2 & Thu Apr 02 11:21:35 2015 \\
\hline $\begin{array}{l}\text { File: C:IPIONA3IFT-0136A_FID2_B.CDF } \\
\text { Sample: FT-00136A }\end{array}$ \\
$\begin{array}{l}\text { Parameter: C:IHPCHEMIHCE4IG95-OLEFIN_2015FID2_B } \\
\text { LIMS Id: }\end{array}$ & Page 1 \\
\hline
\end{tabular}

\section{Calculated Boiling Point}

\begin{tabular}{rr}
$\frac{\text { \%Off }}{\text { IBP }}$ & WBP(F) \\
\hline $5 \%$ & 73.12 \\
$10 \%$ & 97.18 \\
$15 \%$ & 115.32 \\
$20 \%$ & 120.88 \\
$25 \%$ & 144.26 \\
$30 \%$ & 176.35 \\
$35 \%$ & 193.99 \\
$40 \%$ & 209.29 \\
$45 \%$ & 210.17 \\
$50 \%$ & 230.01 \\
$55 \%$ & 233.90 \\
$60 \%$ & 279.66 \\
$65 \%$ & 307.19 \\
$70 \%$ & 316.63 \\
$75 \%$ & 324.43 \\
$80 \%$ & 336.56 \\
$85 \%$ & 336.74 \\
$90 \%$ & 336.91 \\
$95 \%$ & 369.50 \\
FBP & 405.15
\end{tabular}


DETAILED hydROCARbON ANALYSis (DHA) REPORT OF FACE G GASOLINE

\begin{tabular}{|lr|}
\hline Hydrocarbon Expert V4.2 & Thu Apr 02 11:21:35 2015 \\
\hline $\begin{array}{l}\text { File: C:IPIONA3IFT-0136A_FID2_B.CDF } \\
\text { Sample: FT-00136A }\end{array}$ & Page 1 \\
Parameter: C:IHPCHEMIHCE4IG95-OLEFIN_2015FID2_B & Operator: imran \\
LIMS Id: & \\
\hline
\end{tabular}

\section{Calculated Octane Numbers}

$\begin{array}{lrr}\text { Group } & \text { RON } & \text { MON } \\ \text { Paraffin } & 2.81 & 2.71 \\ & 31.72 & 32.09 \\ \text { I-Paraffins } & 0.00 & 0.00 \\ & 40.18 & 37.45 \\ \text { Aromatics } & 0.00 & 0.00 \\ \quad \text { Mono-Aromatics } & 0.00 & 0.00 \\ \quad \text { Naphthalenes } & 1.43 & 1.29 \\ \quad \text { Naphtheno/Olefino-Benz } & & \\ \text { Indenes } & 0.00 & 0.00 \\ \text { Naphthenes } & 10.31 & 8.86 \\ \quad \text { Mono-Naphthenes } & 0.00 & 0.00 \\ \quad \text { Di/Bicyclo-Naphthenes } & & \\ \text { Olefins } & 0.00 & 0.00 \\ \quad \text {-Olefins } & 2.18 & 1.80 \\ \text { Iso-Olefins } & 3.12 & 2.63 \\ \quad \text { Naphtheno-Olefins } & 0.54 & 0.42 \\ \text { Di-Olefins } & 0.00 & 0.00 \\ \quad \text { Oxygenates } & 0.34 & 0.25 \\ \quad \text { Unidentified } & 0.00 & 0.00 \\ \text { Plus } & 0.00 & 0.00\end{array}$

Total Linear RON $=92.64$

Total Linear MON $=87.49$

Total Calculated RON $=99.65$ Total Calculated MON $=87.06$ 


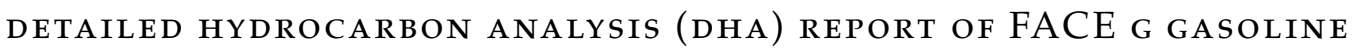

\begin{tabular}{|lr|}
\hline Hydrocarbon Expert V4.2 & Thu Apr 02 11:21:35 2015 \\
\hline $\begin{array}{l}\text { File: C:IPIONA3IFT-0136A_FID2_B.CDF } \\
\text { Sample: FT-00136A }\end{array}$ & Page 1/22/2015 3:23:31 PM \\
Parameter: C:IHPCHEMIHCE4IG95-OLEFIN_2015FID2_B & Operator: imran \\
LIMS Id: & \\
\hline
\end{tabular}

\section{Component List}

\begin{tabular}{|c|c|c|c|c|c|c|}
\hline$\frac{\text { Pk\# }}{1}$ & $\frac{\text { Time }}{7.747}$ & $\frac{\text { Group }}{14}$ & $\frac{\text { Component }}{\mathrm{i}-\text { Butane }}$ & $\frac{\% \text { Wgt }}{0.060}$ & \%Vol & $\frac{\% \text { Mol }}{0.102}$ \\
\hline 2 & 8.095 & P4 & n-Butane & $\begin{array}{l}0.060 \\
2.793\end{array}$ & $\begin{array}{l}0.081 \\
3.618\end{array}$ & $\begin{array}{l}0.102 \\
4.756\end{array}$ \\
\hline 3 & 8.703 & $\mathrm{X} 2$ & Ethanol & 0.259 & 0.246 & 0.556 \\
\hline 4 & 8.976 & C5 & 3-Methylbutene-1 & 0.047 & 0.057 & 0.067 \\
\hline 5 & 9.370 & 15 & i-Pentane & 5.338 & 6.461 & 7.323 \\
\hline 6 & 9.733 & K5 & Pentene-1 & 0.259 & 0.303 & 0.366 \\
\hline 7 & 9.921 & C5 & 2-Methylbutene-1 & 0.552 & 0.637 & 0.779 \\
\hline 8 & 10.061 & P5 & $\mathrm{n}$-Pentane & 0.573 & 0.686 & 0.786 \\
\hline 9 & 10.289 & K5 & t-Pentene-2 & 0.682 & 0.789 & 0.962 \\
\hline 10 & 10.555 & K5 & c-Pentene-2 & 0.384 & 0.440 & 0.542 \\
\hline 11 & 10.729 & C5 & 2-Methylbutene-2 & 1.084 & 1.227 & 1.530 \\
\hline 12 & 11.365 & 16 & 2,2-Dimethylbutane & 2.902 & 3.352 & 3.333 \\
\hline 13 & 12.175 & B5 & Cyclopentene & 0.145 & 0.141 & 0.211 \\
\hline 14 & 12.749 & M5 & Cyclopentane & 7.524 & 7.570 & 10.618 \\
\hline 15 & 12.829 & $\mathrm{C} 6$ & 2,3-Dimethylbutene-1 & 0.601 & 0.659 & 0.706 \\
\hline 16 & 13.050 & 16 & 2-Methylpentane & 1.655 & 1.900 & 1.901 \\
\hline 17 & 13.863 & 16 & 3-Methylpentane & 0.989 & 1.117 & 1.136 \\
\hline 18 & 14.128 & C6 & 2-Methylpentene-1 & 0.179 & 0.196 & 0.211 \\
\hline 19 & 14.185 & K6 & Hexene-1 & 0.293 & 0.324 & 0.345 \\
\hline 20 & 14.807 & C6 & 2-Ethylbutene-1 & 0.062 & 0.067 & 0.073 \\
\hline 21 & 14.871 & P6 & n-Hexane & 0.398 & 0.453 & 0.457 \\
\hline 22 & 14.991 & K6 & t-Hexene-3 & 0.126 & 0.138 & 0.148 \\
\hline 23 & 15.171 & K6 & c-Hexene-3 & 0.258 & 0.282 & 0.303 \\
\hline 24 & 15.325 & K6 & t-Hexene-2 & 0.291 & 0.319 & 0.342 \\
\hline 25 & 15.555 & C6 & 2-Methylpentene-2 & 0.193 & 0.209 & 0.227 \\
\hline 26 & 15.813 & B6 & 4-methylcyclopentene & 0.144 & 0.141 & 0.173 \\
\hline 27 & 16.255 & C7 & 3-methyl-c-pentene-2 & 0.320 & 0.342 & 0.376 \\
\hline 28 & 16.776 & M6 & Methylcyclopentane & 0.801 & 0.803 & 0.942 \\
\hline 29 & 17.052 & 17 & 2,4-Dimethylpentane & 1.393 & 1.553 & 1.376 \\
\hline 30 & 18.667 & B6 & 1-Methylcyclopentene & 0.289 & 0.278 & 0.349 \\
\hline 31 & 18.770 & Q6 & Benzene & 0.473 & 0.404 & 0.600 \\
\hline 32 & 19.648 & M6 & Cyclohexane & 0.280 & 0.270 & 0.329 \\
\hline 33 & 20.536 & 17 & 2-Methylhexane & 1.350 & 1.492 & 1.334 \\
\hline 34 & 20.721 & 17 & 2,3-Dimethylpentane & 2.789 & 3.009 & 2.755 \\
\hline 35 & 21.492 & 17 & 3-Methylhexane & 1.420 & 1.550 & 1.403 \\
\hline 36 & 22.241 & M7 & 1t,3-Dimethylcyclopentane & 0.324 & 0.325 & 0.327 \\
\hline 37 & 22.574 & M7 & 1c,3-Dimethylcyclopentane & 0.283 & 0.285 & 0.285 \\
\hline 38 & 22.701 & 17 & 3-Ethylpentane & 0.166 & 0.178 & 0.164 \\
\hline 39 & 22.905 & M7 & 1t,2-Dimethylcyclopentane & 0.240 & 0.239 & 0.242 \\
\hline 40 & 23.075 & 18 & 2,2,4-Trimethylpentane & 8.164 & 8.848 & 7.074 \\
\hline 41 & 24.543 & P7 & n-Heptane & 1.100 & 1.207 & 1.087 \\
\hline 42 & 27.444 & M7 & Methylcyclohexane & 0.562 & 0.547 & 0.566 \\
\hline 43 & 29.299 & M7 & Ethylcyclopentane & 0.167 & 0.163 & 0.168 \\
\hline
\end{tabular}




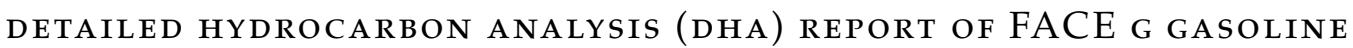

\begin{tabular}{|c|c|}
\hline Thu Apr 02 11:21:35 2015 & Page 2 \\
\hline $\begin{array}{l}\text { File: C:IPIONA3IFT-0136A_FID2_B.CDF } \\
\text { Sample: FT-00136A } \\
\text { Parameter: C:IHPCHEMIHCE4IG95-OLEFIN_2015FID2_B } \\
\text { LIMS Id: }\end{array}$ & $\begin{array}{r}\text { 2/22/2015 3:23:31 PM } \\
\text { Operator: imran }\end{array}$ \\
\hline
\end{tabular}

\section{Component List}

\begin{tabular}{|c|c|c|c|c|c|c|}
\hline$\frac{P k \#}{44}$ & $2 \frac{\text { Time }}{2.519}$ & $\frac{\text { Group }}{18}$ & $\frac{\text { Component }}{25 \text {-Dimethylhexane }}$ & $\frac{\% \text { Wgt }}{0.504}$ & $\frac{\% \text { Vol }}{0.545}$ & $\frac{\% \mathrm{Mol}}{0.37}$ \\
\hline $\begin{array}{l}44 \\
45\end{array}$ & 29.674 & $\begin{array}{l}10 \\
18\end{array}$ & 2,2,3-Trimethylpentane & 0.222 & 0.232 & 0.192 \\
\hline 46 & 29.829 & 18 & 2,4-Dimethylhexane & 0.717 & 0.767 & 0.621 \\
\hline 47 & 32.416 & 18 & 2,3,4-Trimethylpentane & 2.740 & 2.857 & 2.374 \\
\hline 48 & 33.074 & Q7 & Toluene & 4.163 & 3.601 & 4.471 \\
\hline 49 & 34.342 & 18 & 2-Methyl-3-ethylpentane & 0.600 & 0.631 & 0.519 \\
\hline 50 & 35.434 & 18 & 2-Methylheptane & 0.431 & 0.464 & 0.374 \\
\hline 51 & 35.696 & 18 & 4-Methylheptane & 0.147 & 0.156 & 0.127 \\
\hline 52 & 36.756 & M8 & trans-1,3-dimethylcyclohexane & 0.395 & 0.296 & 0.349 \\
\hline 53 & 36.937 & M8 & 1c,2t,3-Trimethylcyclopentane & 0.203 & 0.198 & 0.179 \\
\hline 54 & 38.707 & 19 & 2,2,5-Trimethylhexane & 0.464 & 0.492 & 0.358 \\
\hline 55 & 41.593 & P8 & n-Octane & 0.473 & 0.505 & 0.410 \\
\hline 56 & 51.296 & Q8 & Ethylbenzene & 0.640 & 0.554 & 0.597 \\
\hline 57 & 53.439 & Q8 & m-Xylene & 1.596 & 1.385 & 1.488 \\
\hline 58 & 53.719 & Q8 & p-Xylene & 0.615 & 0.536 & 0.574 \\
\hline 59 & 59.266 & Q8 & o-Xylene & 1.999 & 1.703 & 1.864 \\
\hline 60 & 64.775 & P9 & n-Nonane & 0.230 & 0.241 & 0.178 \\
\hline 61 & 66.544 & Q9 & i-Propylbenzene & 0.357 & 0.311 & 0.294 \\
\hline 62 & 71.687 & 110 & C10 - IsoParaffin - 4 & 1.538 & 1.580 & 1.070 \\
\hline 63 & 72.927 & 110 & 3-Methyl-5-ethylheptane & 5.534 & 5.713 & 3.849 \\
\hline 64 & 73.221 & Q9 & 1-Methyl-3-ethylbenzene & 2.355 & 2.042 & 1.939 \\
\hline 65 & 74.126 & Q9 & 1,3,5-Trimethylbenzene & 3.034 & 2.630 & 2.498 \\
\hline 66 & 75.462 & Q9 & 1-Methyl-2-ethylbenzene & 2.388 & 2.033 & 1.966 \\
\hline 67 & 75.782 & 110 & 2-Methylnonane & 0.171 & 0.176 & 0.119 \\
\hline 68 & 76.677 & 110 & 3-Methylnonane & 0.171 & 0.175 & 0.119 \\
\hline 69 & 77.585 & Q9 & 1,2,4-Trimethylbenzene & 10.409 & 8.912 & 8.571 \\
\hline 70 & 80.013 & C10 & C10-iso-olefin-9 & 0.127 & 0.095 & 0.090 \\
\hline 71 & 80.443 & Q10 & t-Butylbenzene & 0.197 & 0.170 & 0.162 \\
\hline 72 & 81.065 & Q9 & 1,2,3-Trimethylbenzene & 2.001 & 1.678 & 1.648 \\
\hline 73 & 81.381 & Q10 & 1-Methyl-3-i-propylbenzene & 0.278 & 0.242 & 0.205 \\
\hline 74 & 82.362 & Q10 & 1,3-Dimethyl-5-ethylbenzene & 0.623 & 0.531 & 0.460 \\
\hline 75 & 84.553 & Q10 & 1,4,Dimethyl-2-ethylbenzene & 0.296 & 0.253 & 0.218 \\
\hline 76 & 84.847 & Q10 & 1,2-Dimethyl-4-ethylbenzene & 0.722 & 0.620 & 0.533 \\
\hline 77 & 85.261 & Q10 & 1,3-Dimethyl-2-ethylbenzene & 0.367 & 0.309 & 0.270 \\
\hline 78 & 85.370 & I11 & C11 - IsoParaffin - 12 & 0.171 & 0.173 & 0.108 \\
\hline 79 & 85.618 & Q11 & C11 - Aromatic - 1 & 0.645 & 0.544 & 0.431 \\
\hline 80 & 86.501 & Q11 & 1-Methyl-4-t-butylbenzene & 0.221 & 0.195 & 0.147 \\
\hline 81 & 87.614 & Q11 & 1-Ethyl-4-i-propylbenzene & 0.434 & 0.366 & 0.290 \\
\hline 82 & 87.794 & Q10 & 1,2,4,5-Tetramethylbenzene & 0.463 & 0.391 & 0.341 \\
\hline 83 & 88.420 & J11 & 1H-Indene, 2,3-dihydro-1,2-dim & 0.676 & 0.526 & 0.457 \\
\hline 84 & 90.419 & $\mathrm{~J} 10$ & 3-methyl-Indene & 0.149 & 0.116 & 0.114 \\
\hline 85 & 91.630 & Q11 & 1,3-diethyl-5-methyl benzene & 0.304 & 0.268 & 0.203 \\
\hline 86 & 91.952 & Q11 & 1-Methyl-2-n-butylbenzene & 0.428 & 0.360 & 0.286 \\
\hline
\end{tabular}


DETAILED hydROCARbON ANALYSis (DHA) REPORT OF FACE G GASOLINE

\begin{tabular}{|lr|}
\hline Hydrocarbon Expert V4.2 & Thu Apr 02 11:21:35 2015 \\
\hline $\begin{array}{l}\text { File: C:IPIONA3IFT-0136A_FID2_B.CDF } \\
\text { Sample: FT-00136A }\end{array}$ & Page 3 \\
Parameter: C:IHPCHEMIHCE4IG95-OLEFIN_2015FID2_B & 2/22/2015 3:23:31 PM \\
LIMS Id: & Operator: imran \\
\hline
\end{tabular}

\section{Component List}

\begin{tabular}{rrrlrrr} 
Pk\# & Time & Group & Component & \%Wgt & \%Vol & \%Mol \\
\hline 87 & 93.511 & Q11 & C11-Aromatic-11 & 0.293 & 0.259 & 0.196 \\
88 & 94.429 & Q12 & C12-Aromatic-1 & 0.350 & 0.262 & 0.213 \\
89 & 94.847 & P12 & n-Dodecane & 0.182 & 0.181 & 0.106 \\
90 & 96.997 & Q12 & Benzene, 3-ethyl-1,2,4,5-tetramethyl-0.517 & 0.388 & 0.316 \\
91 & 106.108 & J12 & Trimethyl Indene-4 & 0.307 & 0.239 & 0.190 \\
92 & 107.283 & Q11 & Pentamethylbenzene & 0.126 & 0.094 & 0.084 \\
93 & 114.574 & Q12 & 1- Methyl-3-hexyl benzene & 0.114 & 0.096 & 0.070
\end{tabular}




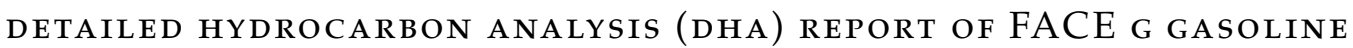

\begin{tabular}{|l|r|}
\hline Hydrocarbon Expert V4.2 & Thu Apr 02 11:21:35 2015 \\
\hline $\begin{array}{l}\text { File: C:IPIONA3IFT-0136A_FID2_B.CDF } \\
\text { Sample: FT-00136A }\end{array}$ & Page 1 \\
Parameter: C:IHPCHEMIHCE4IG95-OLEFIN_2015FID2_B & Operator: imran \\
LIMS Id: &
\end{tabular}

\section{Components by Group}

\begin{tabular}{|c|c|c|c|c|c|}
\hline$\frac{\text { Group }}{\text { Paraffin }}$ & $\begin{array}{r}\text { Time } \\
8.095 \\
10.061 \\
14.871 \\
24.543 \\
41.593 \\
64.775 \\
94.847\end{array}$ & $\begin{array}{l}\text { Component } \\
\text { n-Butane } \\
\text { n-Pentane } \\
\text { n-Hexane } \\
\text { n-Heptane } \\
\text { n-Octane } \\
\text { n-Nonane } \\
\text { n-Dodecane }\end{array}$ & $\begin{array}{l}\text { \%Wgt } \\
2.793 \\
0.573 \\
0.398 \\
1.100 \\
0.473 \\
0.230 \\
0.182\end{array}$ & $\begin{array}{l}\frac{\text { \%ol }}{3.618} \\
0.686 \\
0.453 \\
1.207 \\
0.505 \\
0.241 \\
0.181\end{array}$ & $\begin{array}{l}\text { \%Mol } \\
4.756 \\
0.786 \\
0.457 \\
1.087 \\
0.410 \\
0.178 \\
0.106\end{array}$ \\
\hline I-Paraffins & $\begin{array}{r}7.747 \\
9.370 \\
11.365 \\
13.050 \\
13.863 \\
17.052 \\
20.536 \\
20.721 \\
21.492 \\
22.701 \\
23.075 \\
29.519 \\
29.674 \\
29.829 \\
32.416 \\
34.342 \\
35.434 \\
35.696 \\
38.707 \\
71.687 \\
72.927 \\
75.782 \\
76.677 \\
85.370\end{array}$ & $\begin{array}{l}\text { i-Butane } \\
\text { i-Pentane } \\
\text { 2,2-Dimethylbutane } \\
\text { 2-Methylpentane } \\
\text { 3-Methylpentane } \\
\text { 2,4-Dimethylpentane } \\
\text { 2-Methylhexane } \\
\text { 2,3-Dimethylpentane } \\
\text { 3-Methylhexane } \\
\text { 3-Ethylpentane } \\
\text { 2,2,4-Trimethylpentane } \\
\text { 2,5-Dimethylhexane } \\
\text { 2,2,3-Trimethylpentane } \\
\text { 2,4-Dimethylhexane } \\
\text { 2,3,4-Trimethylpentane } \\
\text { 2-Methyl-3-ethylpentane } \\
\text { 2-Methylheptane } \\
\text { 4-Methylheptane } \\
\text { 2,2,5-Trimethylhexane } \\
\text { C10 - IsoParaffin - 4 } \\
\text { 3-Methyl-5-ethylheptane } \\
\text { 2-Methylnonane } \\
\text { 3-Methylnonane } \\
\text { C11 - IsoParaffin - } 12\end{array}$ & $\begin{array}{l}0.060 \\
5.338 \\
2.902 \\
1.655 \\
0.989 \\
1.393 \\
1.350 \\
2.789 \\
1.420 \\
0.166 \\
8.164 \\
0.504 \\
0.222 \\
0.717 \\
2.740 \\
0.600 \\
0.431 \\
0.147 \\
0.464 \\
1.538 \\
5.534 \\
0.171 \\
0.171 \\
0.171\end{array}$ & $\begin{array}{l}0.081 \\
6.461 \\
3.352 \\
1.900 \\
1.117 \\
1.553 \\
1.492 \\
3.009 \\
1.550 \\
0.178 \\
8.848 \\
0.545 \\
0.232 \\
0.767 \\
2.857 \\
0.631 \\
0.464 \\
0.156 \\
0.492 \\
1.580 \\
5.713 \\
0.176 \\
0.175 \\
0.173\end{array}$ & $\begin{array}{l}0.102 \\
7.323 \\
3.333 \\
1.901 \\
1.136 \\
1.376 \\
1.334 \\
2.755 \\
1.403 \\
0.164 \\
7.074 \\
0.437 \\
0.192 \\
0.621 \\
2.374 \\
0.519 \\
0.374 \\
0.127 \\
0.358 \\
1.070 \\
3.849 \\
0.119 \\
0.119 \\
0.108\end{array}$ \\
\hline \multicolumn{6}{|l|}{ Aromatics } \\
\hline Mono-Aromatics & $\begin{array}{l}18.770 \\
33.074 \\
51.296 \\
53.439 \\
53.719 \\
59.266 \\
66.544 \\
73.221 \\
74.126 \\
75.462 \\
77.585 \\
80.443 \\
81.065\end{array}$ & $\begin{array}{l}\text { Benzene } \\
\text { Toluene } \\
\text { Ethylbenzene } \\
\text { m-Xylene } \\
\text { p-Xylene } \\
\text { o-Xylene } \\
\text { i-Propylbenzene } \\
\text { 1-Methyl-3-ethylbenzene } \\
\text { 1,3,5-Trimethylbenzene } \\
\text { 1-Methyl-2-ethylbenzene } \\
\text { 1,2,4-Trimethylbenzene } \\
\text { t-Butylbenzene } \\
\text { 1,2,3-Trimethylbenzene }\end{array}$ & $\begin{array}{r}0.473 \\
4.163 \\
0.640 \\
1.596 \\
0.615 \\
1.999 \\
0.357 \\
2.355 \\
3.034 \\
2.388 \\
10.409 \\
0.197 \\
2.001\end{array}$ & $\begin{array}{l}0.404 \\
3.601 \\
0.554 \\
1.385 \\
0.536 \\
1.703 \\
0.311 \\
2.042 \\
2.630 \\
2.033 \\
8.912 \\
0.170 \\
1.678\end{array}$ & $\begin{array}{l}0.600 \\
4.471 \\
0.597 \\
1.488 \\
0.574 \\
1.864 \\
0.294 \\
1.939 \\
2.498 \\
1.966 \\
8.571 \\
0.162 \\
1.648\end{array}$ \\
\hline
\end{tabular}


Detailed hydRocarbon ANAlysis (DHA) REPORT of FACE G GASOLINE

\begin{tabular}{|c|c|}
\hline Thu Apr 02 11:21:35 2015 & Page 2 \\
\hline $\begin{array}{l}\text { File: C:IPIONA3IFT-0136A_FID2_B.CDF } \\
\text { Sample: FT-00136A } \\
\text { Parameter: C:IHPCHEMIHCE4IG95-OLEFIN_2015FID2_B } \\
\text { LIMS Id: }\end{array}$ & $\begin{array}{r}\text { 2/22/2015 3:23:31 PM } \\
\text { Operator: imran }\end{array}$ \\
\hline
\end{tabular}

\section{Components by Group}

\begin{tabular}{|c|c|c|c|c|c|}
\hline$\frac{\text { Group }}{\text { Mono-Aromatics }}$ & $\begin{array}{r}\text { Time } \\
81.381 \\
82.362 \\
84.553 \\
84.847 \\
85.261 \\
85.618 \\
86.501 \\
87.614 \\
87.794 \\
91.630 \\
91.952 \\
93.511 \\
94.429 \\
96.997 \\
107.283 \\
114.574\end{array}$ & $\begin{array}{l}\text { Component } \\
\text { 1-Methyl-3-i-propylbenzene } \\
\text { 1,3-Dimethyl-5-ethylbenzene } \\
\text { 1,4,Dimethyl-2-ethylbenzene } \\
\text { 1,2-Dimethyl-4-ethylbenzene } \\
\text { 1,3-Dimethyl-2-ethylbenzene } \\
\text { C11 - Aromatic-1 } \\
\text { 1-Methyl-4-t-butylbenzene } \\
\text { 1-Ethyl-4-i-propylbenzene } \\
\text { 1,2,4,5-Tetramethylbenzene } \\
\text { 1,3-diethyl-5-methyl benzene } \\
\text { 1-Methyl-2-n-butylbenzene } \\
\text { C11 - Aromatic-11 } \\
\text { C12-Aromatic-1 } \\
\text { Benzene, 3-ethyl-1,2,4,5-tetramethyl- } \\
\text { Pentamethylbenzene } \\
\text { 1- Methyl-3-hexyl benzene }\end{array}$ & $\begin{array}{l}\text { \%Wgt } \\
0.278 \\
0.623 \\
0.296 \\
0.722 \\
0.367 \\
0.645 \\
0.221 \\
0.434 \\
0.463 \\
0.304 \\
0.428 \\
0.293 \\
0.350 \\
0.517 \\
0.126 \\
0.114\end{array}$ & $\begin{array}{l}\% \text { Vol } \\
0.242 \\
0.531 \\
0.253 \\
0.620 \\
0.309 \\
0.544 \\
0.195 \\
0.366 \\
0.391 \\
0.268 \\
0.360 \\
0.259 \\
0.262 \\
0.388 \\
0.094 \\
0.096\end{array}$ & $\begin{array}{l}\% \text { Mol } \\
0.205 \\
0.460 \\
0.218 \\
0.533 \\
0.270 \\
0.431 \\
0.147 \\
0.290 \\
0.341 \\
0.203 \\
0.286 \\
0.196 \\
0.213 \\
0.316 \\
0.084 \\
0.070\end{array}$ \\
\hline $\begin{array}{l}\text { Naphthalenes } \\
\text { Naphtheno/Olefir } \\
\text { Indenes }\end{array}$ & $\begin{array}{r}88.420 \\
90.419 \\
106.108\end{array}$ & $\begin{array}{l}\text { 1H-Indene, 2,3-dihydro-1,2-dim } \\
\text { 3-methyl-Indene } \\
\text { Trimethyl Indene - } 4\end{array}$ & $\begin{array}{l}0.676 \\
0.149 \\
0.307\end{array}$ & $\begin{array}{l}0.526 \\
0.116 \\
0.239\end{array}$ & $\begin{array}{l}0.457 \\
0.114 \\
0.190\end{array}$ \\
\hline $\begin{array}{l}\text { Naphthenes } \\
\text { Mono-Naphthen }\end{array}$ & $\begin{array}{l}12.749 \\
16.776 \\
19.648 \\
22.241 \\
22.574 \\
22.905 \\
27.444 \\
29.299 \\
36.756 \\
36.937\end{array}$ & $\begin{array}{l}\text { Cyclopentane } \\
\text { Methylcyclopentane } \\
\text { Cyclohexane } \\
\text { 1t,3-Dimethylcyclopentane } \\
\text { 1c,3-Dimethylcyclopentane } \\
\text { 1t,2-Dimethylcyclopentane } \\
\text { Methylcyclohexane } \\
\text { Ethylcyclopentane } \\
\text { trans-1,3-dimethylcyclohexane } \\
\text { 1c,2t,3-Trimethylcyclopentane }\end{array}$ & $\begin{array}{l}7.524 \\
0.801 \\
0.280 \\
0.324 \\
0.283 \\
0.240 \\
0.562 \\
0.167 \\
0.395 \\
0.203\end{array}$ & $\begin{array}{l}7.570 \\
0.803 \\
0.270 \\
0.325 \\
0.285 \\
0.239 \\
0.547 \\
0.163 \\
0.296 \\
0.198\end{array}$ & $\begin{array}{r}10.618 \\
0.942 \\
0.329 \\
0.327 \\
0.285 \\
0.242 \\
0.566 \\
0.168 \\
0.349 \\
0.179\end{array}$ \\
\hline $\begin{array}{l}\text { Di/Bicyclo-Napht } \\
\text { Olefins } \\
n \text {-Olefins }\end{array}$ & $\begin{array}{r}9.733 \\
10.289 \\
10.555 \\
14.185 \\
14.991 \\
15.171 \\
15.325\end{array}$ & $\begin{array}{l}\text { Pentene-1 } \\
\text { t-Pentene-2 } \\
\text { c-Pentene-2 } \\
\text { Hexene-1 } \\
\text { t-Hexene-3 } \\
\text { c-Hexene-3 } \\
\text { t-Hexene-2 }\end{array}$ & $\begin{array}{l}0.259 \\
0.682 \\
0.384 \\
0.293 \\
0.126 \\
0.258 \\
0.291\end{array}$ & $\begin{array}{l}0.303 \\
0.789 \\
0.440 \\
0.324 \\
0.138 \\
0.282 \\
0.319\end{array}$ & $\begin{array}{l}0.366 \\
0.962 \\
0.542 \\
0.345 \\
0.148 \\
0.303 \\
0.342\end{array}$ \\
\hline Iso-Olefins & $\begin{array}{l}8.976 \\
9.921\end{array}$ & $\begin{array}{l}\text { 3-Methylbutene-1 } \\
\text { 2-Methylbutene-1 }\end{array}$ & $\begin{array}{l}0.047 \\
0.552\end{array}$ & $\begin{array}{l}0.057 \\
0.637\end{array}$ & $\begin{array}{l}0.067 \\
0.779\end{array}$ \\
\hline
\end{tabular}


DETAILED hydROCARbON ANALYSis (DHA) REPORT OF FACE G GASOLINE

\begin{tabular}{|lr|}
\hline Hydrocarbon Expert V4.2 & Thu Apr 02 11:21:35 2015 \\
\hline $\begin{array}{l}\text { File: C:IPIONA3IFT-0136A_FID2_B.CDF } \\
\text { Sample: FT-00136A }\end{array}$ & Page 3 \\
Parameter: C:IHPCHEMIHCE4IG95-OLEFIN_2015FID2_B \\
LIMS Id:
\end{tabular}

\section{Components by Group}

\begin{tabular}{|c|c|c|c|c|c|}
\hline$\frac{\text { Group }}{\text { Iso-Olefins }}$ & $\begin{array}{l}\text { Time } \\
10.729 \\
12.829 \\
14.128 \\
14.807 \\
15.555 \\
16.255 \\
80.013\end{array}$ & $\begin{array}{l}\text { Component } \\
\text { 2-Methylbutene-2 } \\
\text { 2,3-Dimethylbutene-1 } \\
\text { 2-Methylpentene-1 } \\
\text { 2-Ethylbutene-1 } \\
\text { 2-Methylpentene-2 } \\
\text { 3-methyl-c-pentene-2 } \\
\text { C10-iso-olefin-9 }\end{array}$ & $\begin{array}{l}\text { \%Wgt } \\
1.084 \\
0.601 \\
0.179 \\
0.062 \\
0.193 \\
0.320 \\
0.127\end{array}$ & $\begin{array}{l}\frac{\% \text { Vol }}{1.227} \\
0.659 \\
0.196 \\
0.067 \\
0.209 \\
0.342 \\
0.095\end{array}$ & $\begin{array}{l}\frac{\% \mathrm{Mol}}{1.530} \\
0.706 \\
0.211 \\
0.073 \\
0.227 \\
0.376 \\
0.090\end{array}$ \\
\hline Naphtheno-Olefii & $\begin{array}{l}12.175 \\
15.813 \\
18.667\end{array}$ & $\begin{array}{l}\text { Cyclopentene } \\
\text { 4-methylcyclopentene } \\
\text { 1-Methylcyclopentene }\end{array}$ & $\begin{array}{l}0.145 \\
0.144 \\
0.289\end{array}$ & $\begin{array}{l}0.141 \\
0.141 \\
0.278\end{array}$ & $\begin{array}{l}0.211 \\
0.173 \\
0.349\end{array}$ \\
\hline $\begin{array}{r}\text { Di-Olefins } \\
\text { Oxygenates }\end{array}$ & 8.703 & Ethanol & 0.259 & 0.246 & 0.556 \\
\hline
\end{tabular}

Unidentified

Plus 
DETAILED HYDROCARBON ANALYSIS (DHA) REPORT OF FACE G GASOLINE

\begin{tabular}{|lr|}
\hline Hydrocarbon Expert V4.2 & Thu Apr 02 11:21:35 2015 \\
\hline $\begin{array}{l}\text { File: C:IPIONA3IFT-0136A_FID2_B.CDF } \\
\text { Sample: FT-00136A }\end{array}$ & Page 1 \\
Parameter: C:IHPCHEMIHCE4IG95-OLEFIN_2015FID2_B & Operator: imran \\
LIMS Id: & \\
\hline
\end{tabular}

\section{Calculated D86}

$\begin{array}{rr}\frac{\text { \%Off }}{1 \mathrm{BP}} & \text { VBP(F) } \\ 10.0 \% & 123.16 \\ 20.0 \% & 145.15 \\ 30.0 \% & 165.96 \\ 50.0 \% & 196.87 \\ 70.0 \% & 287.84 \\ 80.0 \% & 308.83 \\ 90.0 \% & 323.49 \\ \text { FBP } & 365.86\end{array}$


DETAILED HYDROCARBON ANALYSIS (DHA) REPORT OF FACE G GASOLINE

Hydrocarbon Expert V4.2

File: C:IPIONA3IFT-0136A_FID2_B.CDF

Sample: FT-00136A

Parameter: C:IHPCHEMIHCE4IG95-OLEFIN_2015FID2_B

LIMS Id:
Thu Apr 02 11:21:35 2015

Page 1

2/22/2015 3:23:31 PM Operator: imran

\section{Calculated Physical Properties}

\begin{tabular}{lr} 
Calculated & $\underline{\text { Total }}$ \\
\hline Avg MW & 98.973 \\
Avg SG & 0.763 \\
Avg API @ 60.0F & 57.192 \\
RVP (psi) & 7.539 \\
Tot H & 13.495 \\
C/H & 6.409 \\
Bromine Number & 12.359 \\
Aromatics with 6C (\%weight) & 0.000
\end{tabular}

Recovery $=100.00$ 